\title{
Towards a revised stratigraphy for the Middle to Upper Palaeolithic boundary at La Güelga (Narciandi, Asturias, Spain). Soil micromorphology and new radiocarbon data
}

\author{
M. KehI I (1) , D. Álvarez-Alonso(2), M. de Andrés-Herrero ${ }^{(3,4)}$, P. Carral González ${ }^{(5)}$, E. García ${ }^{(2)}$, \\ J.F. Jordá Pardo ${ }^{(2)}$, M. Menéndez ${ }^{(2)}$, J.M. Quesada ${ }^{(2)}$, J. Rethemeyer ${ }^{(6)}$, J. Rojo ${ }^{(2)}$, Y. Tafelmaier ${ }^{(3,4,7)}$ \\ y Gerd-Christian Weniger ${ }^{(3,4)}$
}

(1) University of Cologne, Institute of Geography, Albertus-Magnus-Platz, D-50923 Cologne, Germany. kehlm@uni-koeln.de

(2) Departamento de Prehistoria y Arqueología, Universidad Nacional de Educación a Distancia, Ciudad Universitaria, Paseo Senda del Rey 7, E-28040 Madrid, Spain.

mmenendez@geo.uned.es,dalvarez@gijon.uned.es, egarciasmail@gmail.com,jjorda@geo.uned.es, juliorojo@juliorojo.jazztel.es, jmquesada@geo.uned.es

(3) Neanderthal Museum. Talstr. 300, D-40822 Mettmann, Germany. weniger@neanderthal.de, tafelmaier@neanderthal.de, mdeandres@neanderthal.de

(4) University of Cologne, Institute of Prehistoric Archaeology, Albertus-Magnus-Platz, D-50923 Cologne, Germany. (5) Departamento de Geología y Geoquímica, Universidad Autónoma de Madrid, Campus de Cantoblanco, E-28049 Madrid, Spain. pilar.carral@uam.es

(6) University of Cologne, Institute for Geology and Mineralogy, Albertus-Magnus-Platz, D-50923 Cologne, Germany. janet.rethemeyer@uni-koeln.de

(7) University of Tübingen, Institute for Early Prehistory and Quaternary Ecology, Burgsteige 11, D-72070 Tübingen, yvonne.tafelmaier@uni-tuebingen.de

\begin{abstract}
The archaeological sequence of the Palaeolithic site of La Güelga apparently shows an interstratification of Aurignacian between the Mousterian and Châtelperronian layers, a sequence which disagrees with the stratigraphic model for the Middle to Upper Palaeolithic transition in SW-Europe. We analyzed the witness section of the interior sector in archaeological zone $D$ using micromorphology and collected new radiocarbon dates for the Aurignacian and presumably Châtelperronian levels in order to provide detailed sediment descriptions of the site and scrutinize the presumed interstratification. Thin sections from Mousterian levels 8 and 9 show microstratification, signs of trampling and preferential sub-horizontal orientation of elongated particles. These features are less strongly developed in the Aurignacian deposit of levels 5 and 6 and are lacking in the presumably Châtelperronian ones of levels 1 and 2. The deposits of the latter show other features of reworked slope deposits such as a randomized distribution of limestone clasts. Radiocarbon dating on bone samples from level 2 places this layer to between $\sim 41.5$ and $45 \mathrm{ka}$ cal BP, hence older than Aurignacian level 5 , dated to between $\sim 35.5$ and $41.5 \mathrm{ka}$ cal BP. Comparative dating of bones with and without ultrafiltration pretreatment conducted in two different laboratories yielded results in excellent agreement. Overall, the micromorphological observations and new radiocarbon ages strongly suggest that the few finds of presumably Châtelperronian affinity and sediments of levels 1 and 2 were transported by slope processes into the shelter.
\end{abstract}

Key words: Pleistocene, karst, La Güelga, datation, soil micromorphology.

\section{Hacia una revisión de la estratigrafía del paso entre el Paleolítico medio y el superior de la cueva de La Güelga (Narciandi, Asturias, España). Micromorfología de suelos y nuevas fechas radiocarbónicas}

\section{RESUMEN}

La secuencia arqueológica del yacimiento paleolítico de La Güelga muestra, aparentemente, una interestra- 
Kehl, M., et al., 2018. Towards a revised stratigraphy for the Middle to Upper... Boletín Geológico y Minero, 129 (1/2): 183-206

tificación auriñaciense entre los niveles del Musteriense y Chatelperroniense, una secuencia que difiere del modelo estratigráfico para la transición del Paleolítico medio al superior en el SO de Europa. Hemos analizado el testigo existente en la zona $D$ interior, tomando muestras para micromorfología, y realizado nuevas dataciones radiocarbónicas para los niveles auriñacienses y chatelperronienses, con el objetivo de aportar una detallada descripción sedimentológica del yacimiento y analizar a fondo esta presunta interestratificación. Las láminas delgadas de los niveles 8 y 9, musterienses, muestran microestratificación, señales de trampling y una orientación preferente sub-horizontal de los elementos alargados. Estas características están presentes en una menor proporción en los niveles 5 y 6, auriñacienses, y están ausentes en el presunto chatelperroniense de los niveles 1 y 2. Los últimos dos niveles presentan muchas evidencias que remiten a los depósitos de ladera removidos, como por ejemplo la distribución aleatoria de los clastos de caliza, ausencia de compactación por trampling y de microestratificación. Las dataciones radiocarbónicas de las muestras

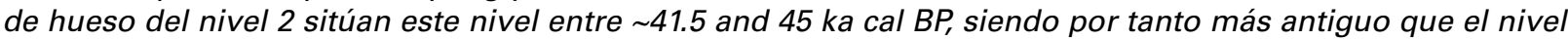
5, Auriñaciense, datado entre $\sim 35.5$ and $41.5 \mathrm{ka}$ cal BP. Al comparar la datación de huesos con y sin pretratamiento de ultrafiltración realizadas en dos laboratorios diferentes se han obtenido resultados muy similares. En general los resultados micromorfológicos y las nuevas dataciones radiocarbónicas, aportan datos sólidos que sugieren que los escasos restos atribuidos por afinidad al Chatelperroniense, en los niveles 1 y 2, fueron transportados por procesos de ladera hacia el interior del abrigo.

Palabras clave: Pleistoceno, karst, La Güelga, datación, micromorfología de suelo.

\section{VERSION ABREVIADA EN CASTELLANO}

\section{Introducción y metodología}

El tecnocomplejo chatelperroniense, generalmente asociado con Neandertales (Hublin et al., 2012), juega un papel importante dentro del debate de la transición del Paleolítico medio al superior, así como en la aparición de los humanos anatómicamente modernos en el oeste de Europa, con el Auriñaciense como su cultura material. Las interestratificaciones entre industrias auriñacienses y chatelperronienses han sido usadas para apoyar escenarios de interacción entre neandertales y humanos modernos (Gravina et al., 2005; Mellars et al., 2007). Sin embargo, la revisión de los datos arqueológicos y tafonómicos de sitios como Le Piage y Rocde-Combe (Bordes, 2003) o El Pendo (Hoyos and Laville, 1982; Montes and Sanguino, 2001, Montes et al., 2005), ponen en entredicho las propuestas interestratificaciones, que principalmente se sostienen en un escenario de coexistencia sustentado por el modelo de aculturación. Dentro de este contexto, el yacimiento de La Güelga (Fig. 1) es de especial importancia. Es uno de los pocos sitios que muestran posibles evidencias de ocupación chatelperroniense en el norte de España. Además, este yacimiento también posee niveles musterienses y auriñacienses, siendo estos últimos para los que se ha planteado, en publicaciones previas, una interestratificación con niveles chatelperronienses (Menéndez et al., 2005; Quesada López and Menéndez Fernández, 2009). La transición del Paleolítico medio al superior se localiza en la zona $D$, que a su vez ha sido dividida en una zona interior y otra exterior (Fig. 2 and 3). Basándose en los análisis sedimentológicos y mineralógicos así como en las dataciones radiocarbónicas, parece probable que los depósitos musterienses de las zonas interior y exterior se puedan correlacionar entre sí (Jordá Pardo et al., 2013). En general, el conjunto lítico del Chatelperroniense de los niveles 1 y 2 es reducido y apenas diagnóstico. Los niveles 5 y 6 de La Güelga han sido atribuidos al Auriñaciense y subyacen a los posibles restos chatelperronienses en la zona $D$ interior (Quesada López and Menéndez Fernández, 2009: 50).

El contexto cronoestratigráfico existente no es indiscutible (Menéndez et al., 2014). Las dataciones radiocarbónicas sobre dos muestras de hueso de los niveles 1 y 2 aportaron una edad reciente, situada entre 34 y 39 ka cal BP para el Chatelperroniense y otra datación radiocarbónica sobre hueso para la base de la secuencia musteriense del interior, situada en el mismo rango (Menéndez et al., 2005). Posteriores dataciones de radiocarbono sobre otras muestras de hueso ofrecieron fechas considerablemente más antiguas para el Musteriense, situando esta ocupación entre 56 y 45 ka cal BP (Quesada López and Menéndez Fernández, 2009; Maroto et al., 2012; Jordá Pardo et al., 2013), tras desechar las dataciones más recientes, previamente publicadas. Esta circunstancia también arroja dudas sobre la fiabilidad de las dataciones disponibles para el Chatelperroniense. La contradicción entre los datos cronométricos, la complejidad de los procesos de formación del yacimiento, la naturaleza poco diagnóstica de los restos arqueológicos -por otra parte escasos-, exige una revisión crítica de los datos disponibles en La Güelga con el fin de valorar su importancia de cara al presente debate.

Hemos llevado a cabo análisis micromorfológicos de la secuencia de La Güelga para obtener un mejor conocimiento de los procesos de formación del depósito arqueológico y de la estratigrafía de este importante yacimiento. Se estudiaron diez láminas delgadas de las zonas interior y exterior, usando para ello un microscopio petrográfico. Además, tres muestras de hueso de los niveles 2 y 5 fueron analizadas con y sin el 
Kehl, M., et al., 2018. Towards a revised stratigraphy for the Middle to Upper... Boletín Geológico y Minero, 129 (1/2): $183-206$

pretratamiento de ultrafiltración, en los laboratorios de Oxford (ORAU) y Colonia (CologneAMS). Basándonos en estos datos, proponemos un marco cronoestratigráfico revisado para las ocupaciones del Paleolítico medio y superior de La Güelga. En las tablas 1 y 2 , y en la figura 4, se aporta una pequeña descripción de la secuencia sedimentológica, incluyendo los principales restos arqueológicos y la localización de las muestras de micromorfología.

\section{Resultados y discusión}

Las láminas delgadas muestran las típicas características micromorfológicas que se encuentran en las secuencias arqueológicas dentro de las cuevas calizas (secuencia interior) y en los depósitos de ladera ricos en fragmentos de caliza (secuencia exterior). La estructura general puede deducirse a partir de las imágenes de las láminas delgadas obtenidas en un escáner de lecho plano que se muestran en las figuras 5 y 6 . La cantidad de material grueso incluyendo calizas y fragmentos de cuarcita (Fig. 8 A-D), carbón, hueso, sílex (Fig. 8 E) así como coprolitos (Fig. 9 C, D) varía entre los diferentes niveles arqueológicos (Fig. 7, Tabla 3). Existe una tendencia al aumento de materiales arqueológicos relevantes según se va profundizando dentro de la secuencia interior. En la fracción de arenas y limos dominan los granos de cuarzo, mientras que se detectaron escasos fragmentos de caliza o granos de calcita (Fig. $8 \mathrm{G}, \mathrm{H}$ ). Además, aparecen algunos granos de mineral opaco (Fig. 8 F). El material fino presenta un color que va de marrón rojizo a marrón oscuro (luz polarizada plana, PPL) con apariencia punteada. La estructura es principalmente de puntos y manchas, pero también aparecen localmente estructuras granoestriadas bien desarrolladas. Localmente, están presentes unos recubrimientos de polvo muy fino de arcillas y limos, inferiores aproximadamente a 20 um de grosor (Fig. 9 A). La disolución de la calcita en los bordes de los fragmentos de caliza provoca zonas de erosión. La presencia de calcita secundaria es escasa. Los fragmentos de caliza de la zona interior tienen los bordes fosfatados, indicando la precipitación de fosfato (Fig. 8, A y B). Además, el fosfato aparece en los fragmentos de coprolitos de carnívoros (Fig. 9 C y D). No se han detectado cenizas en los sedimentos. Las láminas delgadas de la zona exterior muestran características más claras y abundantes de edafización que las láminas de la zona interior, incluyendo moteados bien desarrollados, estructuras paralelas estriadas y granoestriadas, frecuentes coberturas de arcillas impuras, microestructuras de bloques subangulares mejor representadas y coberturas y nódulos de carbonatos secundarios.

Se pueden señalar varias características importantes para diferenciar entre niveles arqueológicos intactos y revueltos. La primera está relacionada con la compactación por trampling, que se indica por la presencia de materiales machacados como huesos o conchas (por ejemplo, Goldberg et al., 2009, Miller et al., 2010, Linstädter and Kehl, 2012, Estévez et al., 2014) o mediante la comparación diferencial del sedimento (Goldberg et al., 2009). El trampling se observa en las láminas delgadas 5, 6, 8 y 9 de la zona interior de La Güelga, donde es evidente la presencia de huesos triturados o de capas compactadas de manera diferencial (Fig. 9, E y F). La segunda característica es la microestratificación (Courty, 2001) que en La Güelga implica una intercalación de microestratos ricos en carbón (Fig. $8 A, 9 E$ y G) o capas de diferente granulometría media (Fig. $9 \mathrm{H}$ ). Las mezclas por bioturbación, la acción del hielo o el transporte de ladera habrían destruido las interfaces entre microestratos produciendo, finalmente, niveles no estratificados verticalmente. Finalmente, si existió un suelo de ocupación lo más probable es que los ejes longitudinales de los fragmentos alargados como los huesos, utensilios líticos o los fragmentos de caliza, fueran depositados paralelamente en esta superficie dando como resultado una orientación planar de los elementos alargados. En La Güelga, las láminas delgadas en las que se manifiesta más claramente una presencia de orientación preferencial horizontal o subhorizontal son las $L G 6,8$ y 9, mientras que es menos evidente en las láminas $L G$ 1, 2, 4 y 5 (Tabla 4). La mayoría de las características micromorfológicas de los niveles presumiblemente chatelperronienses, 1 y 2, indican que no existen evidencias de niveles arqueológicos intactos. En general, las láminas delgadas de los niveles 1 y 2 muestran muchas características que se encuentran en los materiales de los depósitos de ladera, pobremente ordenados (Betran and Texier, 1999). Es mucho más probable que los sedimentos del nivel 1 y 2 fueran transportados hacia la zona interior de la cueva debido a un deslizamiento del suelo.

Se han obtenido dos nuevas dataciones radiocarbónicas de un fragmento de hueso del nivel 2 (Tabla 3). Estas fechas cubren una horquilla entre 41.5 y $46.0 \mathrm{ka}$ cal BP (Tabla 5, Fig. 10), por lo que son más antiguas que las dataciones obtenidas previamente para los niveles 1 y 2 (Tabla 5), lo que podría estar relacionado con que en este caso se aplicaron, para estas muestras, unos métodos de pretratamiento más rigurosos. Si estas nuevas fechas datan la ocupación chatelperroniense de La Güelga, ésta tuvo lugar entre la acumulación de los niveles musterienses y auriñacienses (Fig. 10). Se utilizaron dos muestras de hueso del nivel 5, para su análisis en los laboratorios ORAU y CologneAMS empleando los métodos de pretratamiento convencional y de ultrafiltración. Las edades de ${ }^{14} \mathrm{C}$ obtenidas muestran una excelente concordancia acentuando la fiabilidad del método de datación. Incluyendo los resultados de Beta-377233 (Tabla 5), la ocupación auriñaciense está datada entre $\sim 35.6$ y $41.7 \mathrm{ka}$ cal BP, y por lo tanto, después de la ocupación presumiblemente chatelperro- 
Kehl, M., et al., 2018. Towards a revised stratigraphy for the Middle to Upper... Boletín Geológico y Minero, 129 (1/2): 183-206

niense. La inversión en la edad hacia la parte superior de la secuencia apoya la idea de que al menos el nivel 2 está formado por sedimentos revueltos.

En conclusión, las láminas delgadas de los sedimentos de los niveles musterienses y auriñacienses en La Güelga muestran muchas características de los depósitos arqueológicos intactos. Por el contrario, los sedimentos de los niveles chatelperronienses carecen de esas características y muestran otras típicas de los depósitos revueltos. Esto sugiere que, después de la caída parcial del techo documentada en el nivel 3 de la zona interior, los sedimentos junto con unos pocos restos de industria lítica fueron transportados hacia el interior del abrigo debido a un deslizamiento del suelo. Las dataciones radiocarbónicas indican unas edades más jóvenes para los niveles auriñacienses que para los chatelperronienses. Esta inversión en la edad se suma al hecho de que los sedimentos removidos se sitúan por encima de las superficies de ocupación auriñacienses. El nuevo marco cronooestratigráfico sugiere un vacío ocupacional entre el Musteriense y el Auriñacienses de al menos $2.5 \mathrm{ka}$ entre ca. 44.5 y $42 \mathrm{ka}$ cal BP. Teniendo en cuenta las débiles evidencias arqueológicas y estratigráficas de la ocupación chatelperroniense, parece improbable que el periodo de abandono del yacimiento fuese interrumpido por algo más que unas ocupaciones esporádicas en La Güelga.

\section{Introduction}

The Châtelperronian technocomplex, generally associated with Neanderthals (Leroi-Gourhan, 1961; Lévêque and Vandermeersch 1980; Hublin et al., 2012; Hublin 2015; critical: Bar-Yosef and Bordes, 2010), plays a major role within the discussion of the Middle to the Upper Palaeolithic transition and the appearance of anatomically modern humans in western Europe with the Aurignacian as its material output. On the one hand, the Châtelperronian has been interpreted as the archaeological manifestation of an acculturative process, in which incoming Homo sapiens populations acculturated Neanderthals (Mellars, 1996 and 2005). On the other hand, the innovative behaviour represented by the Châtelperronian industry has been claimed by others to originate independently of the Homo sapiens' influence (e.g. d'Errico et al., 1998), thereby emphasizing Neanderthal intellectual capacities (Zilhão and d'Errico, 1999). In this context, interstratifications of Aurignacian and Châtelperronian assemblages have been used to support Neanderthal and modern human interaction scenarios (Gravina et al., 2005; Mellars et al., 2007) as described in the first hypothesis. However, a revision of the archaeological and taphonomic data of sites such as Le Piage and Rocde-Combe (Bordes, 2003), or El Pendo (Hoyos and Laville, 1982; Montes and Sanguino, 2001; Montes et al., 2005) call into question the postulated interstratifications. Thus, at the moment no unequivocal interstratifications of Aurignacian and Châtelperronian occupations sustaining a coexistence scenario as assumed by the acculturation model exist.

Within this context the site of La Güelga located in Asturias, northern Spain (Fig. 1) is of special importance. It is one of the few sites showing possible evidence for a Châtelperronian occupation in northern Spain. Besides, the site also yields Mousterian and
Aurignacian deposits, whereas for the latter an interstratification with the Châtelperronian layers of the site had been claimed in earlier publications (Menéndez et al., 2005; Quesada López and Menéndez Fernández, 2009, Menéndez et al., 2014). The zone of interest in the context of the Middle to Upper Palaeolithic transition is zone $D$, which has been divided into an interior and an exterior zone. Excavations in that area have been conducted since 2000 under the direction of Mario MenéndezFernández (Menéndez et al., 2005; Quesada López and Menéndez Fernández, 2009). The correlation of the exterior and the interior zone is complicated by cryoturbated and bioturbated areas in between (Quesada López and Menéndez Fernández, 2009: 44), but based on sedimentological and mineralogical investigations as well as new radiocarbon data, it appears likely that the Mousterian deposits of the interior and exterior zones correlate with each other (Jordá Pardo et al., 2013; Menéndez et al., 2014).

Levels 1 and 2 in the interior part have been attributed to the Châtelperronian mainly based on the presence of one (Quesada López and Menéndez Fernández, 2009: 48) or two (Jordá-Pardo et al., 2013; Menéndez et al. 2014) Châtelperron point(s) discovered in level 1. In general, the lithic assemblage is small and rather undiagnostic and contains sidescrapers and denticulates as well as burins and retouched blades (Jordá Pardo et al., 2013: 90). The application of the Levallois concept is also indicated by the presence of several Levallois flakes (Jordá Pardo et al., 2013: 90). Level 2 yielded only six modified artefacts, among them denticulates, side-scrapers and modified blades (Quesada López and Menéndez Fernández, 2009). Although Châtelperron points were lacking, the similarities with the overlying assemblage led to the ascription to the Châtelperronian (Quesada López and Menéndez Fernández, 2009: 49). Layers 5 and 6 of La Güelga 


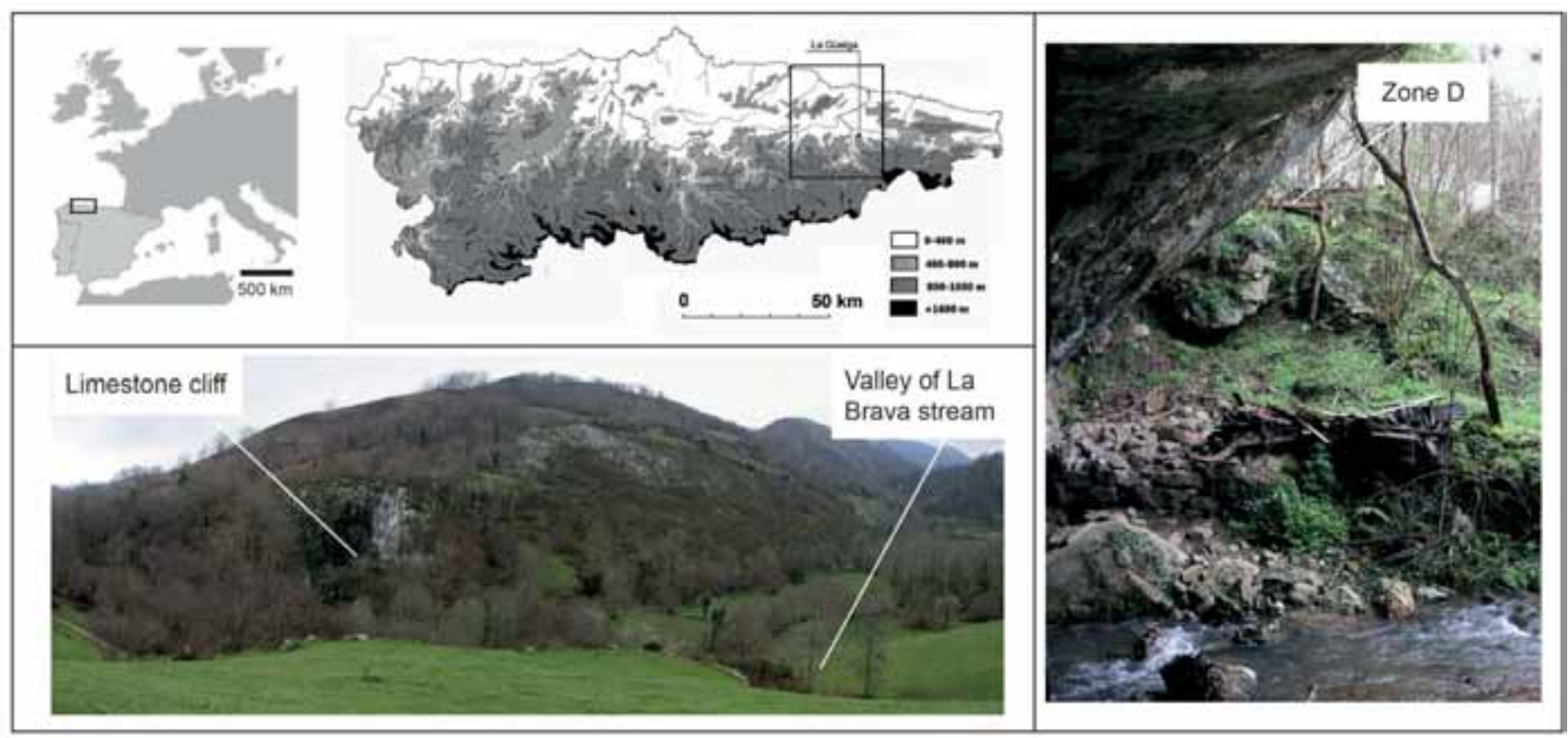

Figure 1. Location of La Güelga in Asturias, northern Spain (adapted from Jordá-Pardo et al., 2013). The photograph at the bottom shows the valley of La Brava stream and the cliff above the archaeological site. The picture on the right shows the location of archaeological zone D above the swallet of La Brava stream.

Figura 1. Situación de La Güelga en Asturias, norte de España (adaptada de Jordá Pardo et al., 2013). La fotografía de abajo muestra el valle del arroyo de La Brava y la peña en la que se abre el yacimiento arqueológico. La figura de la derecha muestra la localización de la zona $D$ sobre la dolina del arroyo de La Brava.

have been attributed to the Aurignacian and underlie the possible Châtelperronian remains of levels 1 and 2 in the zone D interior (Quesada López and Menéndez Fernández, 2009: 50).

Moreover, the existing chronostratigraphic framework is not unequivocal. Radiocarbon dating on two bone samples from levels 1 and 2 (zone D interior) yielded a recent age between about 34 and $39 \mathrm{ka} \mathrm{cal}$ BP for the Châtelperronian and another radiocarbon date on bone from the Mousterian context of the interior sequence fell in the same age range (Menéndez et al., 2005). Further radiocarbon dating on other bone samples offered different, considerably older dates for the Mousterian, placing the occupation between 56 to $45 \mathrm{ka}$ cal BP (Quesada López and Menéndez Fernández, 2009; Maroto et al., 2012; Jordá Pardo et al., 2012; Menéndez et al., 2014) and rejecting the young ages previously published for the Middle Palaeolithic at La Güelga. This also casts doubt on the reliability of the available dates for the Châtelperrronian. The contradicting chronometric data, the complex site formation processes involved, the scarcity and undiagnostic nature of the archaeological remains as well as the fact that recent studies falsified previously stated interstratifications at other locations, demands for a critical re-evaluation of the available data at La Güelga in order to assess its significance for the current debate.

Therefore, an inevitable prerequisite is the thorough understanding of sediment accumulation and alteration processes in zone $D$ in order to solve the complex stratigraphic situation and to verify or falsify the putative Châtelperronian - Aurignacian interstratification (Menéndez et al., 2014). A crucial point is to clarify if all the layers of the archaeological deposit accumulated in place or if any layer has been laterally reworked and originated from outside the cave. In the latter case, the sediments and embedded artefacts would not be in primary position and would not represent the time of occupation and spatial organization of site use. For clarification of this issue, granulometric and fabric analyses of the size distribution and spatial orientation of artefacts have successfully been used for Palaeolithic sites in France (e.g. Lenoble and Bertran, 2004; Bertran et al., 2012). The methods require detailed data on the length, width, orientation and dip of artefacts, which is not available for the sequences of La Güelga. In addition, the density of archaeological finds is very low for the presumably Châtelperronian occupations, which hampers statistical evaluation. The micromorphological study of sediment thin sections gives insight into the composition 
and fabric of sediments providing clues on processes of sediment deposition and post-depositional alteration (e.g., Courty et al., 1989; Goldberg and Macphail, 2006; Goldberg and Berna, 2011). Natural processes of deposition, e.g. by gravity, fluvial action or chemical precipitation and diagenetic changes including bioturbation, pedogenesis or precipitation of secondary minerals are often clearly indicated in micromorphological properties (e.g., Courty et al., 1989). Human occupation and sequential accumulation of anthropogenic and natural materials leave characteristic features including evidence for trampling, presence of microdebitage and microstratification (Courty, 2001). The latter consists, for instance, of intercalated microlayers rich in either charcoal or ash separated from each other by clear interfaces. If microstratification is preserved, lateral reworking of sediments and embedded artefacts is very unlikely, because reworking over a certain distance would destroy internal interfaces and mixing during transport resulted in randomized deposits (Courty, 2001). However, natural processes including fluvial deposition may also yield microstratified layers. These often do not include anthropogenic materials though. Mixing in place by bioturbation may destroy internal boundaries, but would also leave typical fingerprints. Micromorphology may thus help to distinguish between undisturbed and disturbed from laterally reworked archaeological layers.

In the following, we describe results of new micromorphological investigations of the sequence at $\mathrm{La}$ Güelga. Our aim was to better understand site formation processes and finally the stratigraphy at this important site in northwest Spain. Special attention was paid to which micromorphological features may be helpful for distinguishing undisturbed, disturbed and reworked deposits.

Finally, we present results of eight new radiocarbon datings on three bone samples from the presumably Châtelperronian level 2 and from Aurignacian level 5 studied pre-treated with and without ultrafiltration at the Oxford Radiocarbon Accelerator unit (ORAU) and the Cologne radiocarbon dating laboratory (CologneAMS). We discuss these new and former radiocarbon dates and propose a revised chronostratigraphic framework for the Middle to Upper Palaeolithic occupations at La Güelga.

\section{Zone D at La Güelga}

The archaeological site of La Güelga includes four excavation zones $A$ to $D$ (Fig. 1) located at the end of a blind valley south of the swallet of La Brava (or La
Güelga) river at an altitude of $182 \mathrm{~m}$ above sea level. Here, the river enters a subterranean karstic complex developed within limestone of the pre-Stephanian Upper Carboniferous Barcaliente formation, which morphotectonically belongs to the eastern part of the Asturian Massif or the central zone of the Cantabrian Cordillera. This formation consists of grey and black micrites, microsparites and dolomicrites with occasional collating marls showing massive to platy stratification and has a thickness between 140 and $300 \mathrm{~m}$ (I.G.M.E., 1986). At the swallet, a cliff about $20 \mathrm{~m}$ high was formed in the limestone. Successive phases of river incision during karst formation are represented by hanging subterranean galleries and up to seven stepped terraces or shelves and notches of fluviokarstic origin. The archaeological zone $D$ is located at $11 \mathrm{~m}$ above the current river channel where a small river terrace is preserved. It lies on top of about $2 \mathrm{~m}$ thick chaotic deposits of large limestone blocks detached from the cliff. Above these blocks, a former entrance to the cave system is preserved where the river once flowed and probably disappeared into the limestone. The cavity is rather small and was completely filled with sediments. The excavation uncovered three openings to the cavity and exposed the detailed interior archaeological sequence (Figs. 2 and 3 ). This sequence is presently connected to sediments outside the cavity, excavated on a surface area of about $9 \mathrm{~m}^{2}$ (Fig. 2). Here, the exterior sequence of zone $\mathrm{D}$ was recorded. It begins with the $11 \mathrm{~m}$-terrace and is partly covered by younger archaeologically sterile slope deposits. It is likely that it represents a collapsed part of a former rock shelter (Quesada López and Menéndez Fernández, 2009; Jordá Pardo et al., 2013). In its lower part archaeological levels assigned to the Mousterian were uncovered. Within and outside the cavity excavation did not reach the bedrock.

Detailed field descriptions of the sediment sequences are given in Quesada López and Menéndez Fernández (2009) and Jordá Pardo et al. (2013), which are summarized together with details on the archaeological assemblages of each level of the interior and exterior sequences in Tables 1 and 2, respectively, and in the text below. The interior sequence was divided into two surface layers covering an archaeological sequence of nine levels. Two surface layers and five archaeological levels were distinguished for the exterior sequence, of which level 4 was divided into two separate layers (4a and 4b). Detailed data on granulometry, carbonate content and organic matter content were presented by Jordá Pardo et al. (2013), who also analysed the bulk mineralogic composition of the silt + clay size fraction (grains $<63 \mu \mathrm{m}$ in equivalent diameter) using $X$-ray 


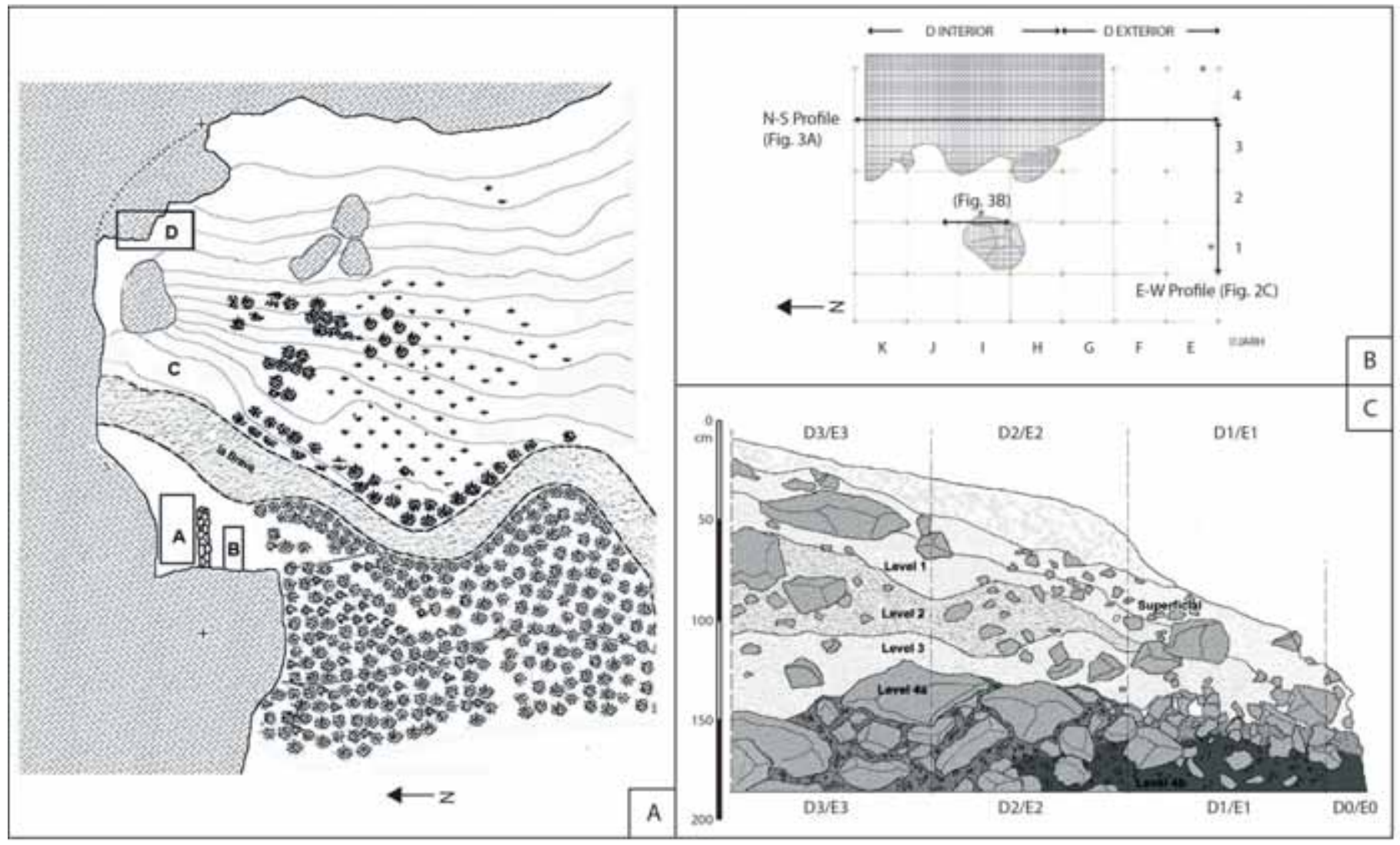

Figure 2. A: Location of archaeological zones $A, B, C$ and D at La Güelga; redrawn from Quesada Lopéz and Ménendez Fernández (2009). $\mathrm{B}$ : Excavation plan and distinction in interior and exterior sectors of zone $\mathrm{D}$ at La Güelga. The location of profile sketched in Figure $2 \mathrm{C}$ and Figure $3 \mathrm{~A}$ and $3 \mathrm{~B}$ are indicated by black lines. Stars indicate the locations of sampling for micromorphology. C: East-west longitudinal profile showing the deposits excavated in the exterior sector (adapted from Jordá Pardo et al., 2013).

Figura 2. A: Localización de las zonas arqueológicas $A, B, C$ y $D$ en La Güelga: redibujado a partir de Quesada López y Menéndez Fernández (2009). B. Plano de la excavación y diferenciación de las áreas interior y exterior de la zona $D$ en La Güelga. Se indica mediante líneas negras la situación del perfil esbozado en la Fig. 2C y en la Fig. $3 A$ y 3B. Las estrellas indican la ubicación de los muestreos para micromorfología. C. Perfil longitudinal E-W que muestra los depósitos excavados en la zona exterior (adaptado de Jordá Pardo et al., 2013).

diffraction (XRD). According to that study, all sediments of the interior sequence classified as muddy sandy gravels with bimodal, trimodal or polymodal grains size curves. The fine earth fraction $(<2 \mathrm{~mm})$ belonged to the texture classes of muddy and silty sands. The carbonate content ranged between about $2.5 \%$ and $15.0 \%$ and organic matter between $0.15 \%$ and $1.14 \%$ (according to Table 2 in Jordá-Pardo et al., 2013). The XRD bulk mineralogical composition was dominated by quartz and mica. While calcite was found in all levels in small amounts, feldspar and chlinochlore occurred in the lower levels. Locally, gypsum, dolomite, and kaolinite were detected in small amounts. The latter two minerals only occurred in the two lowest levels. Low amounts of gypsum were observed in most levels. In the exterior sequence, granulometry was characterized by bi- to polymodal grain size distributions and classified as gravels, sandy gravels and muddy sandy gravels. The fine earth belonged to the textural classes of sands, muddy sands and silty sands. The organic matter content ranged between $0.41 \%$ in level $4 \mathrm{~b}$ and $1.60 \%$ or even $4.58 \%$ in level 5 and surface level 2 , respectively (according to Table 2 in Jordá-Pardo et al., 2013). Carbonate contents showed a wide range between less than $10 \%$ in most layers and values between 17 $\%$ and $28 \%$ in levels 1,2 and $4 \mathrm{~b}$. The XRD bulk mineralogical composition was dominated by quartz and mica and showed larger amounts of calcite than detected for the interior sequence. Interestingly, hydroxyapatite was detected at low concentration $>5$ $\%$ in all levels.

The sediments of the interior sequence slope towards the interior, whereas sediments in the external sector show a double slope, i.e. towards the interior of the cave as well as towards the exterior. As based on the geometry of the deposits as well as on their granulometric and mineralogic characteristics, Jordá 


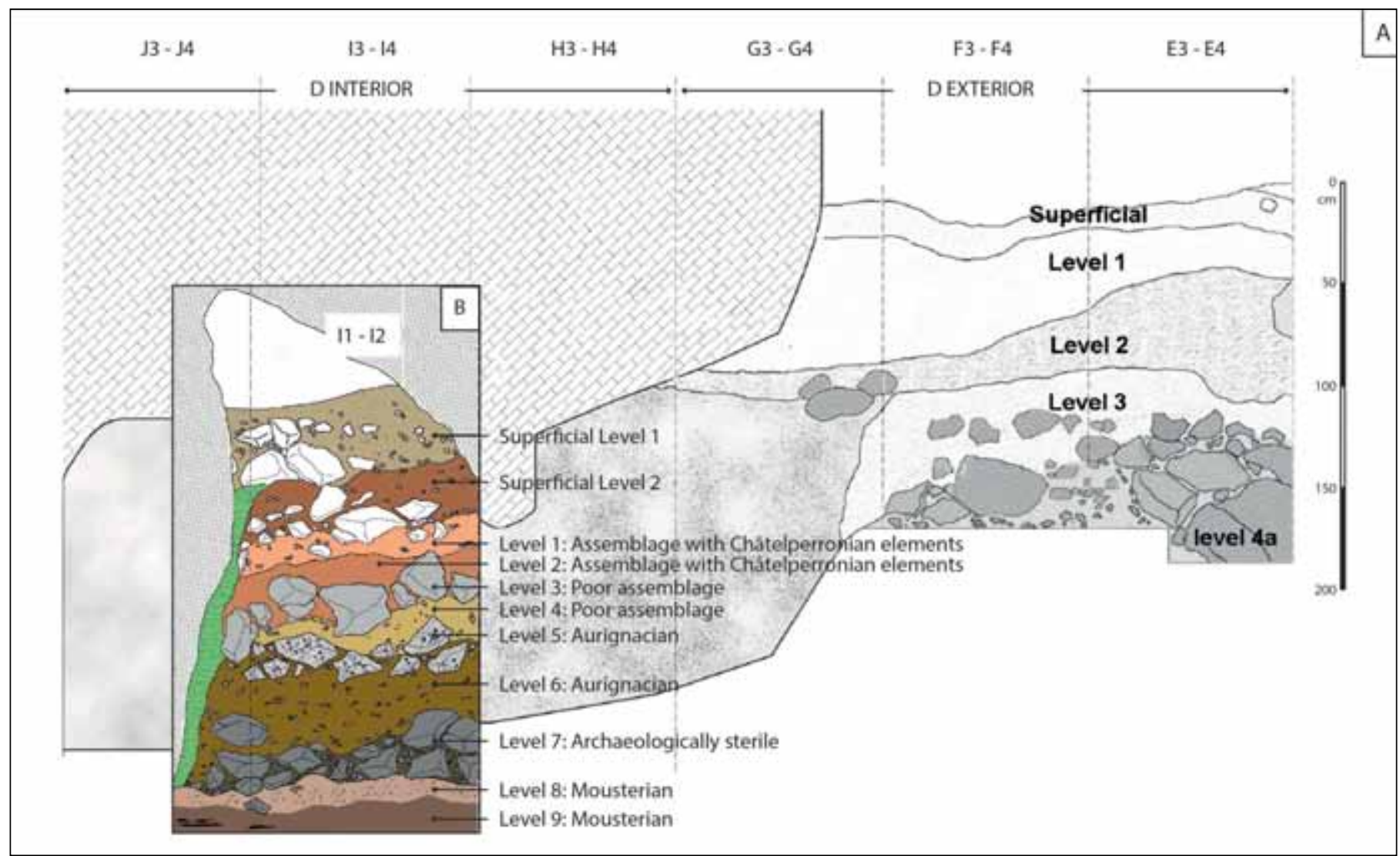

Figure 3. A: North-south profile covering the sediment sequence of zone D exterior (adapted from Jordá-Pardo et al., 2013). B: Sketch of the sampled profile (Fig. 4A) of zone D interior with overall stratigraphy (from Menéndez et al., 2014, changed). Note that the location of this profile is along squares I1 and I2. According to Jordá-Pardo et al. (2013) and Menéndez et al. (2014), level 4a of zone D exterior can be correlated with level 7 of zone D interior and level $4 \mathrm{~b}$ exterior (underlying level $4 \mathrm{a}$ as shown in Fig. 2C) with levels 8 and 9 interior.

Figura 3. A. Perfil N-S que muestra la secuencia sedimentaria de la zona D exterior (adaptado de Jordá Pardo et al., 2013). B. Imagen del perfil muestreado (Fig. 4A) de la zona D interior con toda la estratigrafía (modificado de Menéndez et al., 2014). Téngase en cuenta que este perfil se sitúa a lo largo de los cuadros 11 e I2. Según Jordá-Pardo et al. (2013) y Menéndez et al. (2014), el nivel 4a de la zona D exterior puede correlacionarse con el nivel 7 de la zona $D$ interior; y el nivel $4 b$ de la zona $D$ exterior (infrayacente al nivel $4 a$, como se muestra en la Fig. 2C) con los niveles 8 y 9 de la zona $D$ interior.

Pardo et al. (2013) suggested correlation of levels 7 with $4 \mathrm{a}$ and $8 / 9$ with $4 \mathrm{~b}$ of the interior and exterior sequences, respectively (see Fig. 3). As based on the lithic assemblages, the charcoal-rich horizon of level 9 should be considered as the inward extension of the Mousterian occupation outside the cave (Jordá-Pardo et al., 2013; Menéndez et al., 2014). This correlation may be verified by more detailed mineralogical or geochemical investigations in future studies.

\section{Methods}

\section{Micromorphology}

We extracted a series of nine sediment monoliths from the south profile of square 12 in the interior sector and one sample each from the north profile of square $\mathrm{E} 3$ and from the east profile of square E0, both located in the exterior sector of zone D (Fig. 2, 4). All sediment monoliths were taken from the central parts of archaeological levels. Due to the high stone content, levels 3 and 7 were not sampled and the monoliths had to be reinforced by plaster bandages but partial loss of sediment occurred while monolith LG1 was taken out. For comparison, we also took two samples from obviously bioturbated parts of the interior sequence. Sample LG-R was taken from loosely packed bioturbated sediment of an animal burrow with few charcoal pieces and small bone fragments to the left of the studied profile depicted in Figure 4 and sample LG-P1 from very loosely packed deposits of the bioturbated zone at the right side of the profile.

The sediment monoliths were air-dried, impregnated with artificial resin and cut into slices in order to prepare thin sections $(60 \mathrm{~mm}$ wide, $80 \mathrm{~mm}$ high, 

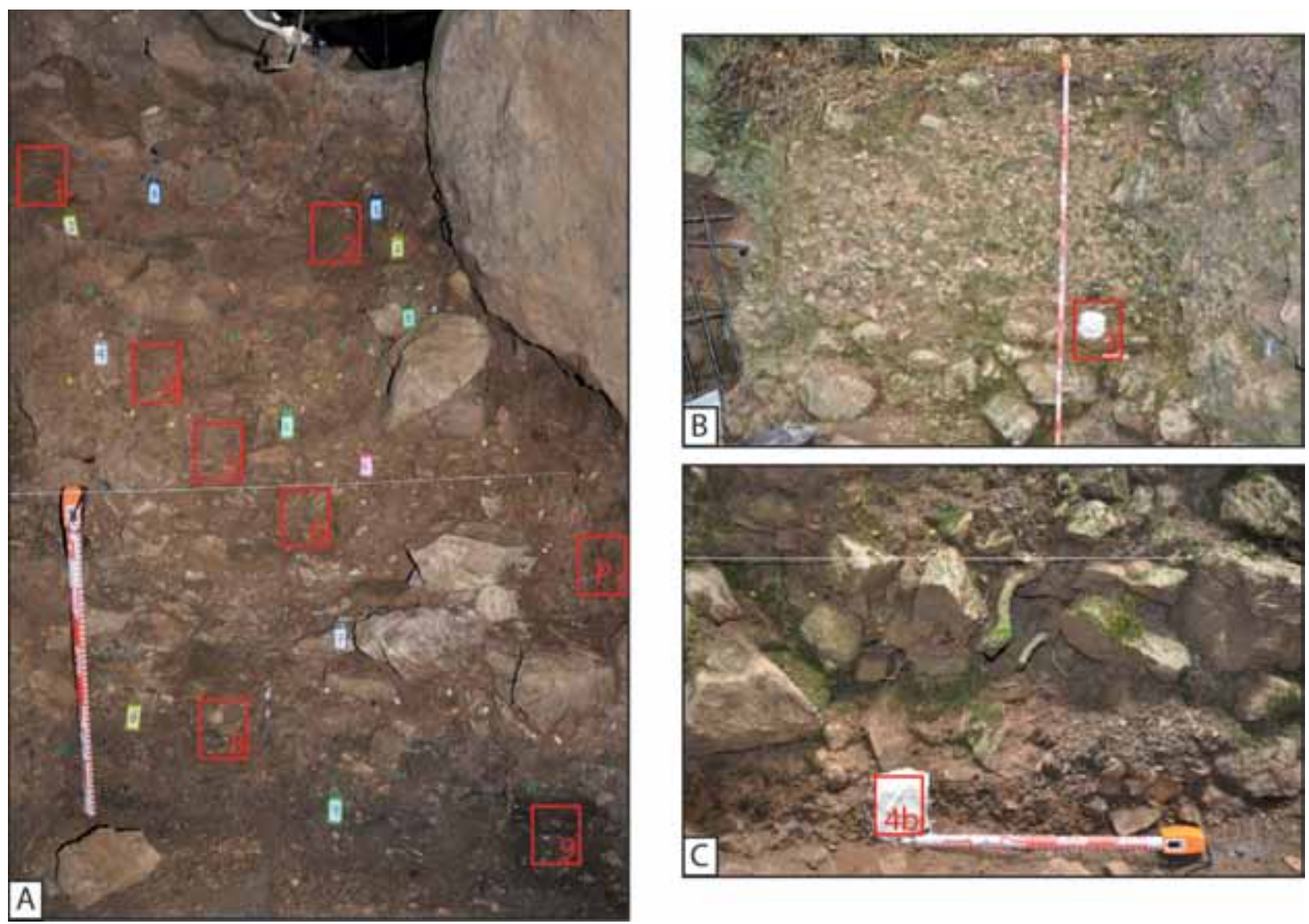

Figure 4. Sampling locations (red rectangles) of undisturbed sediment blocks for micromorphological investigations. The numbering follows the numbers of the archaeological levels sampled. A) Profile I1/2 to J1/2 (for sketch see Fig. 3B). The sample P1 was taken from bioturbated sediment near the shelter wall. Small tags on the photograph indicate the archaeological levels. B) The slope deposits of profile F4-E4, see Figure 2B for sampling location. C: The south profile of square E1 (see also Figure $2 \mathrm{C}$ ).

Figura 4. Localización de las muestras (rectángulos rojos) de bloques de sedimentos no alterados para el análisis micromorfológico. Su numeración sigue los números de los niveles arqueológicos muestreados. A) Perfil de 11/2 a J1/2 (ver Fig. 3B). La muestra P1 fue tomada de sedimentos bioturbados cerca del muro del abrigo. Unas pequeñas etiquetas en la fotografía indican los niveles arqueológicos. B) Depósitos de ladera del perdil F4-E4, ver Figura 2 para la ubicación del muestreo. C) Perfil Sur del cuadro E1 (ver también Figura 2C).

$30 \mu \mathrm{m}$ thick) according to procedures described in Beckmann (1997). The description of micromorphological features widely follows the terminology suggested by Stoops (2003). Micromorphological investigations were conducted with a polarizing microscope under plain polarized light (PPL), crossed polarizers (XPL) and oblique incident light (OIL) at magnifications of $20 x$ to $400 x$. The thin sections were also analysed at lower magnification after scanning with a flatbed scanner at resolution of $1200 \mathrm{dpi}$. Thin section scans at 300 dpi resolution are shown in Figures 5 and 6 . For characterising sediment composition and structure, we mapped coarse limestone and quartzite fragments as well as coprolites and archaeologically relevant components including charcoal, bone and flint (Fig. 7). Calcite coatings on larger rock fragments are also indicated.
The thin sections were extracted in vertical orientation but provide two-dimensional images only. The angle between the plane of the section and the studied objects is not known, hence the orientation of elongated particles cannot be deduced (Stoops, 2003). In addition to the thin section itself, slices of the impregnated blocks were used to observe the orientation of the elongated fragments.

\section{Radiocarbon dating}

During extraction of sediment monoliths from level 2, a well preserved bone fragment from Bos sp. (sample ID B1-2012) was taken out of the sediment profile. Two bone fragments of unknown species attribution were taken from different squares of Aurignacian level 5 
Kehl, M., et al., 2018. Towards a revised stratigraphy for the Middle to Upper... Boletín Geológico y Minero, 129 (1/2): $183-206$

\begin{tabular}{|c|c|c|c|}
\hline Archaeological level & Sedimentological description & Notes on archaeological finds & Thin section \\
\hline Surface level 2 & $\begin{array}{l}18 \text { to } 35 \mathrm{~cm} \text { thick deposit of autochthonous angular boulders } \\
\text { and cobbles as well as allochthonous rounded cobbles } \\
\text { embedded in pale-brown matrix of silty sand. Few fragments } \\
\text { of karstified limestone. }\end{array}$ & None & Not sampled \\
\hline $\begin{array}{l}\text { Level } 1 \text { (presumably } \\
\text { Châtelperronian) }\end{array}$ & $\begin{array}{l}10 \text { to } 20 \mathrm{~cm} \text { thick deposit of pale brown muddy sand with } \\
\text { autochthonous angular pebbles and allochthonous rounded } \\
\text { cobbles. Sloping towards the interior of the cavity. Few pieces } \\
\text { of charcoal and bone fragments. }\end{array}$ & $\begin{array}{l}\text { Quartzite side-scrapers and } \\
\text { denticulates, few flint burins } \\
\text { and retouched blades, some } \\
\text { Levallois blanks and a presu- } \\
\text { mably Châtelperronian point, } \\
\text { retouched flakes }\end{array}$ & LG 1 \\
\hline $\begin{array}{l}\text { Level } 3 \text { (poor assem- } \\
\text { blage) }\end{array}$ & $\begin{array}{l}\text { About } 10 \mathrm{~cm} \text { thick deposit of large autochthonous slightly } \\
\text { rounded clasts embedded in brown muddy sand. }\end{array}$ & $\begin{array}{l}\text { Few quartzite notches and } \\
\text { some retouched flakes }\end{array}$ & Not sampled \\
\hline $\begin{array}{l}\text { Level } 4 \text { (poor assem- } \\
\text { blage) }\end{array}$ & $\begin{array}{l}12 \text { to } 20 \mathrm{~cm} \text { thick deposit of light brown muddy sand with } \\
\text { autochthonous pebbles and rounded gravel and chaotic } \\
\text { arrangement. }\end{array}$ & $\begin{array}{l}\text { Two double side-scrapers in } \\
\text { flint and quartzite }\end{array}$ & LG 4 \\
\hline Level 5 (Aurignacian) & $\begin{array}{l}6 \text { to } 20 \mathrm{~cm} \text { thick deposit of brown muddy sand with autoch- } \\
\text { thonous pebbles. }\end{array}$ & $\begin{array}{l}\text { Lithic elements more laminar } \\
\text { than in levels above, flint com- } \\
\text { ponent is important }\end{array}$ & LG 5 \\
\hline Level 6 (Aurignacian) & $\begin{array}{l}30 \text { to } 40 \mathrm{~cm} \text { thick deposit of autochthonous cobbles and peb- } \\
\text { bles with an abundant dark brown matrix of muddy sand. } \\
\text { Planar orientation of clasts parallel to the sub-horizontal } \\
\text { depositional surface. }\end{array}$ & $\begin{array}{l}\text { Bones with intentionally modi- } \\
\text { fied aspect including a perfora- } \\
\text { ted red deer phalange and } \\
\text { antler point }\end{array}$ & LG 6 \\
\hline
\end{tabular}

Table 1. Short sedimentological description of the interior sequence at La Güelga zone D according to Jordá Pardo et al. (2013) as well as own observations and list of thin sections taken from the south profile of square 12 (Fig. 4).

Tabla 1. Breve descripción sedimentológica de la secuencia interior de la zona D de La Güelga según Jordá Pardo et al. (2013), así como observaciones propias y listado de láminas delgadas tomadas del perfil sur en el cuadro 12 (Fig. 4).

during excavation in 2002. The three bone samples were used for ${ }^{14} \mathrm{C}$ dating of collagen extracts at the laboratories of ORAU and CologneAMS. Both laboratories applied ultrafiltration methods for collagen extraction to avoid age underestimation due to contamination with young ${ }^{14} \mathrm{C}$ (Ramsey, 2004; Rethemeyer et al.,). The CologneAMS also tested ${ }^{14} \mathrm{C}$ dating of the same bone samples without ultrafiltration. The pretreatment and measuring procedures of
ORAU are detailed in Ramsey et al., $(2002,2004)$ and Brock et al., (2007, 2013) while analytical details on previous ORAU datings at La Güelga can be found in Jordá Pardo et al., (2012). More information on procedures at CologneAMS is given in Rethemeyer et al. (2013) and Fülöp et al. (2013).

In addition, a collagen extract of another bone sample from level 5 (Aurignacian) was analysed by BetaAnalytics. Calibration of radiocarbon dates was 
Kehl, M., et al., 2018. Towards a revised stratigraphy for the Middle to Upper... Boletín Geológico y Minero, 129 (1/2): $183-206$

\begin{tabular}{|c|c|c|c|}
\hline Archaeological level & Sedimentological description & Notes on archaeological finds & Thin section \\
\hline Surface level 1 & $\begin{array}{l}25 \mathrm{~cm} \text { thick deposit of black muddy sand including sparse } \\
\text { autochthonous clasts and abundant organic matter }\end{array}$ & $\begin{array}{l}\text { Mixed material of variable chro- } \\
\text { nology }\end{array}$ & Not sampled \\
\hline Surface level 2 & $\begin{array}{l}20 \mathrm{~cm} \text { thick deposit of brown and partly black muddy sand } \\
\text { with autochthonous limestone boulders, cobbles and peb- } \\
\text { bles. The deposit shows a slope towards the exterior. }\end{array}$ & None & Not sampled \\
\hline $\begin{array}{l}\text { Level } 1 \text { (very poor } \\
\text { assemblage) }\end{array}$ & $\begin{array}{l}15 \text { to } 20 \mathrm{~cm} \text { thick conglomerate of autochthonous cobbles } \\
\text { and pebbles including a matrix of light brown muddy sand. }\end{array}$ & $\begin{array}{l}\text { Few pieces of lithic production } \\
\text { debris }\end{array}$ & Not sampled \\
\hline $\begin{array}{l}\text { Level } 3 \text { (few remains } \\
\text { of Mousterian) }\end{array}$ & $\begin{array}{l}30 \text { to } 40 \mathrm{~cm} \text { thick conglomerate of autochthonous boulders, } \\
\text { cobbles and pebbles with a light brown matrix of muddy } \\
\text { sand. Moderate cementation by secondary carbonate. }\end{array}$ & $\begin{array}{l}\text { Few archaeological remains } \\
\text { with Mousterian characteristics, } \\
\text { mostly crusted }\end{array}$ & LG 3 \\
\hline $\begin{array}{l}\text { Level } 5 \text { (poor assem- } \\
\text { blage) }\end{array}$ & $\begin{array}{l}60 \mathrm{~cm} \text { thick deposit of muddy sand with light brown silty } \\
\text { loam and autochthonous boulders and cobbles progressively } \\
\text { decreasing in size towards the base. Cobbles are angular and } \\
\text { show alteration. }\end{array}$ & $\begin{array}{l}\text { Scarce archaeological material } \\
\text { decreasing in number down- } \\
\text { wards }\end{array}$ & Not sampled \\
\hline
\end{tabular}

Table 2. Short sedimentological description of the exterior sequence at La Güelga zone D according to Jordá Pardo et al. (2013) as well as own observations and list of thin sections taken from the exterior sector of zone D (Fig. 4).

Tabla 2. Breve descripción sedimentológica de la secuencia exterior en la zona D de La Güelga, según Jordá Pardo et al. (2013), así como observaciones propias y listado de láminas delgadas extraídas de la zona D-exterior.

accomplished using the CalPal-2007-Hulu dataset (Weninger and Jöris, 2008) and the CalPal software package (Weninger et al., 2007).

\section{Results and discussion}

\section{Micromorphology}

\section{General characteristics}

The thin sections exhibit typical micromorphological features often encountered in archaeological sequences within limestone caves (interior sequence) and slope deposits rich in limestone debris (exterior sequence). Rock fragments larger than about $1 \mathrm{~mm}$ in diameter consist of mainly micritic limestone and angular to well-rounded quartzite (Fig. 8A-D). The limestone fragments have angular shape and most of them derive from slabbing off the cave wall. Some sub-rounded fragments occur as well, probably due to fluvial transport by the former La Güelga River. The quartzite is composed of slightly elongated interlock- ing quartz grains and contains very few other minerals including green (PPL) mineral grains with bright green interference colour. Quartzite outcrops in the catchment of La Güelga River (Jordá Pardo et al., 2013) and was also used for the production of lithic tools. Spherical and rounded quartzite particles included in thin sections probably experienced fluvial transport. Flint with cryptocrystalline quartz is present in thin section as well (Fig. 8E). Most flint and some quartzite fragments show microfeatures characteristic of knapped artefacts such as smooth surfaces or prominent boundaries (Angelucci, 2010). In addition, some opaque mineral grains occur. These show banded fabrics, reddish brown to brown colour under OIL and high porosity (Fig. 8F). These properties are common in disorthic iron oxide nodules or fragments of iron oxide crusts (ferricretes). Further coarse components are fragments of charcoal and bone, the latter showing low to moderate degrees of corrosion and in some cases also burning.

In the sand and medium to coarse silt fraction, quartz grains dominate, whereas few limestone fragments or calcite grains were detected (Fig. 8G, H). This 

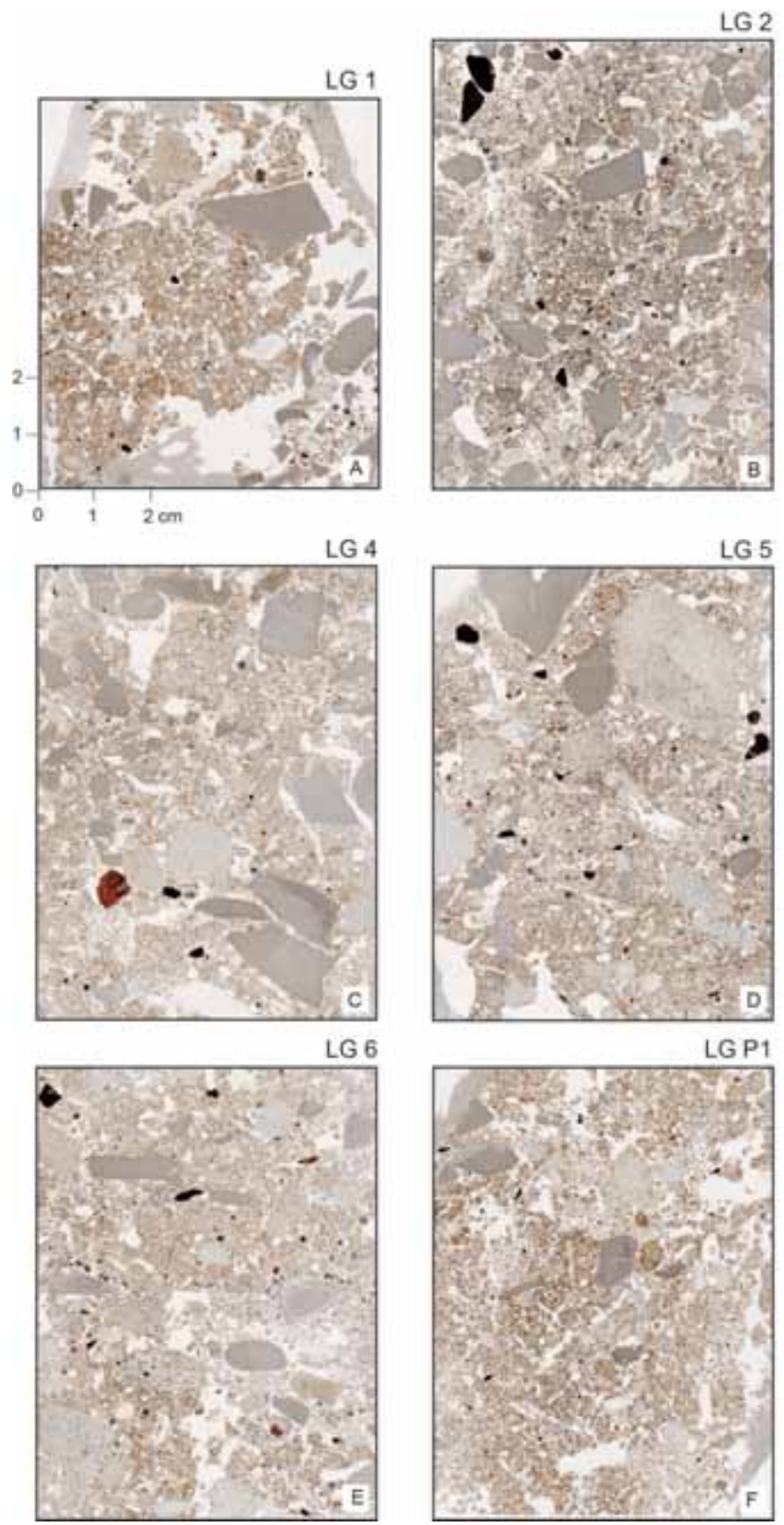

Figure 5. Flatbed scans of thin sections extracted from the Upper Palaeolithic levels (levels LG 1, 2, 4, 5, 6) and from the bioturbated facies along the cave wall (LG P1).

Figura 5. Escaneado plano de las láminas delgadas extraídas de los niveles del Paleolítico superior (niveles $L G 1,2,4,56$ ) y de la facies bioturbada situada a lo largo del muro de la cavidad (LG P1).

is in agreement with the overall low carbonate content as measured in the fine earth fractions $(<2 \mathrm{~mm})$ of sediment samples from the two sequences (Jordá Pardo et al., 2013).
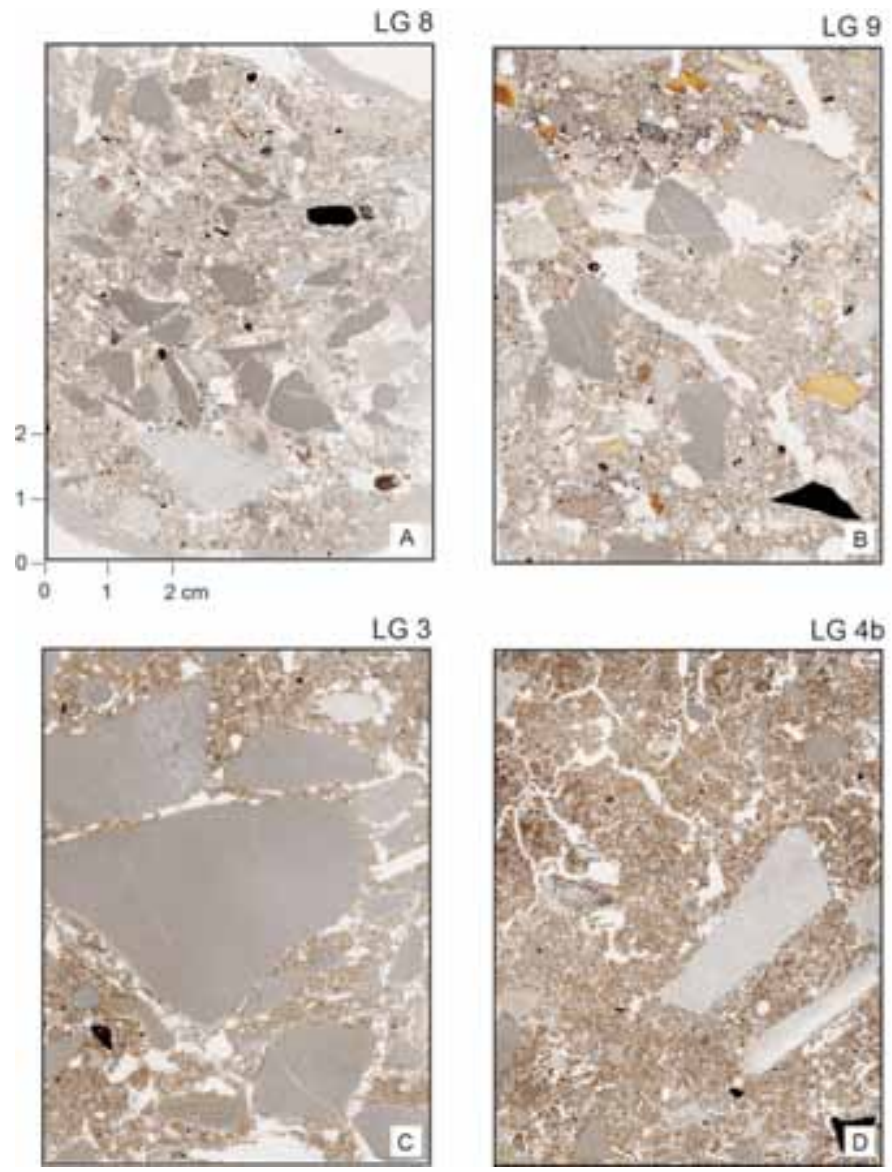

Figure 6. Flatbed scans of thin sections extracted from the Middle Palaeolithic levels (interior levels 8 and 9, exterior levels 3 and 4b). Figura 6. Escaneado plano de las láminas delgadas de los niveles del Paleolítico medio (niveles de la zona D interior 8 y 9; niveles de la zona $D$ exterior 3 y $4 b$ ).

The fine material (micromass) has a reddish brown to dark brown colour (PPL) and dotted appearance. The b-fabric is mainly stipple-speckled, but locally well-developed granostriated b-fabric occurs. Very thin dusty clay plus silt coatings, less than approximately $20 \mu \mathrm{m}$ thick, are present locally (Fig. 9 A). These coatings show diffuse extinction lines.

Along the edges of limestone fragments, dissolution of calcite caused formation of weathering zones. Secondary calcite is rare. Few infillings were detected in the interior sequence but outside the cave, the large rock fragments often show calcite coatings (Fig. 9B), which preferentially formed along the lower edge of the fragments reflecting percolation of bicarbonate rich soil water.

Phosphatic rims in limestone fragments from the interior section indicate precipitation of phosphate (Fig. 8A and B). Furthermore, phosphate occurs as coprolites of elongated to circular shape with diame- 


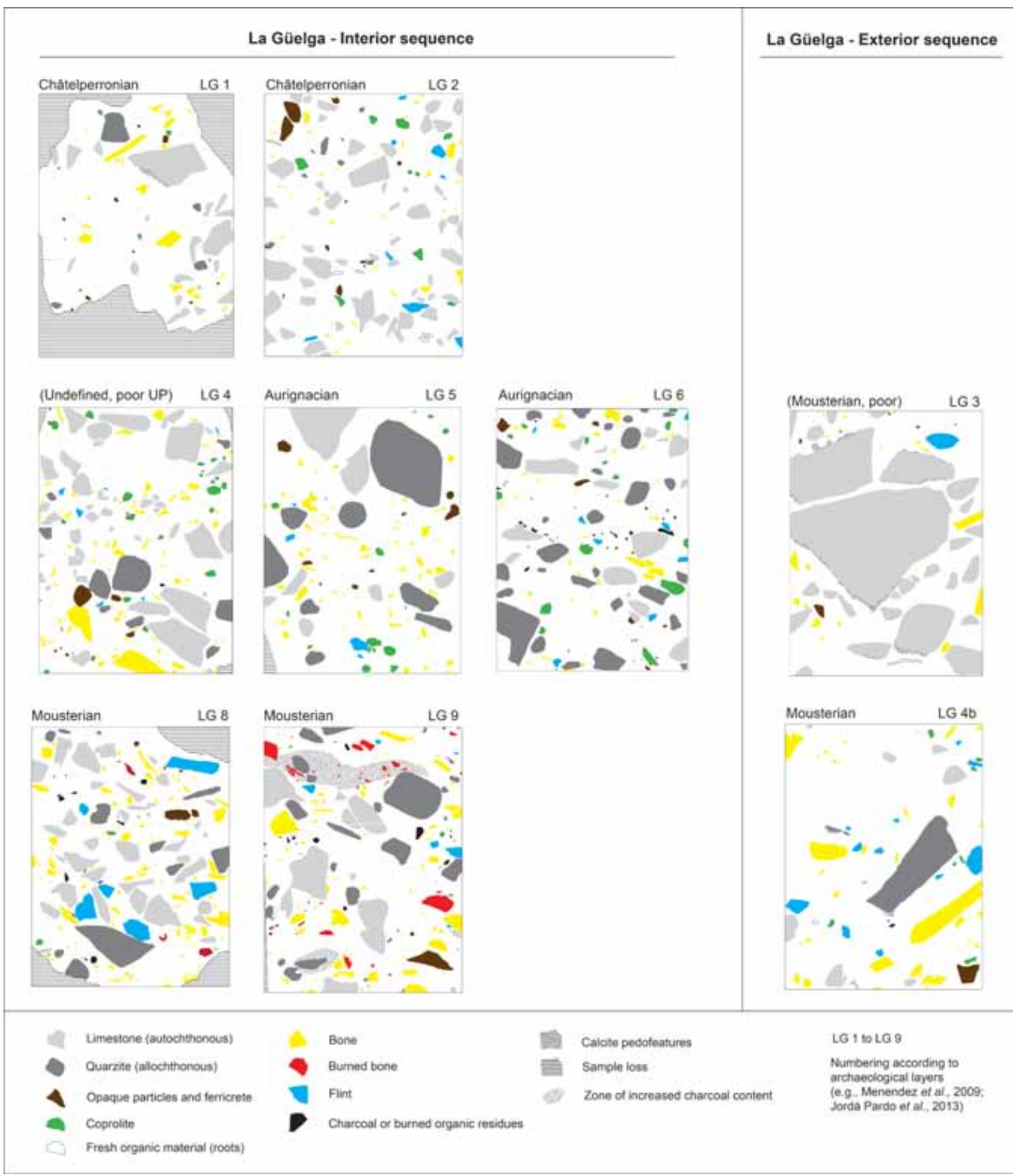

Figure 7. Map of the large components (>2 mm) in thin sections of La Güelga. The amount of archaeologically relevant pieces (charcoal, bone, flint) is higher in the Mousterian layers than in the Aurignacian or Châtelperronian ones. Note that quarzite fragments in the thin sections from levels 1 and 2 (Châtelperronian) are very rare.

Figura 7. Mapa de los componentes de gran tamaño $(>2 \mathrm{~mm}$ ) en las láminas delgadas de La Güelga. La cantidad de elementos arqueológicos relevantes (carbón, hueso, sílex) es más elevado en los niveles musterienses que en los auriñacienses o chatelperronienses. Señalar que los fragmentos de cuarcita en las láminas delgadas de los niveles 1 y 2 (Chatelperronienses) son muy escasos. 
LG 6; frame width $-5 \mathrm{~mm} ; \mathrm{PPL}$

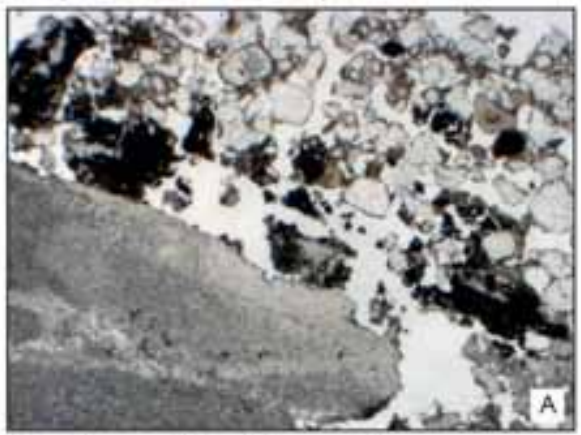

LG 5; frame width $\sim 2.5 \mathrm{~mm} ; \mathrm{PPL}$

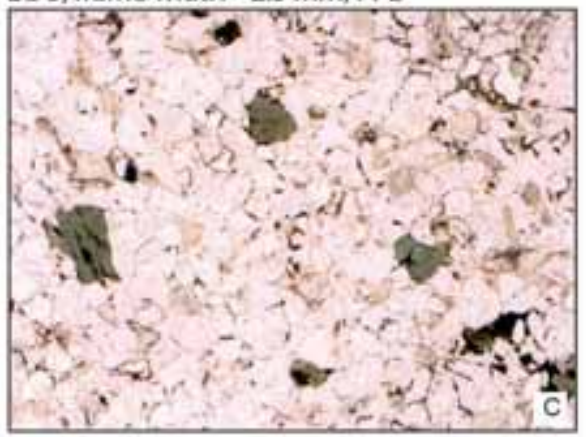

LG 2: frame width $\sim 2.5 \mathrm{~mm} ; \mathrm{PPL}$

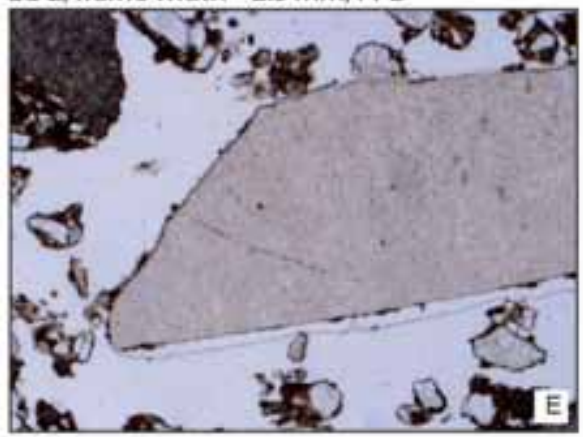

LG 3; frame width $\sim 5 \mathrm{~mm}$; PPL

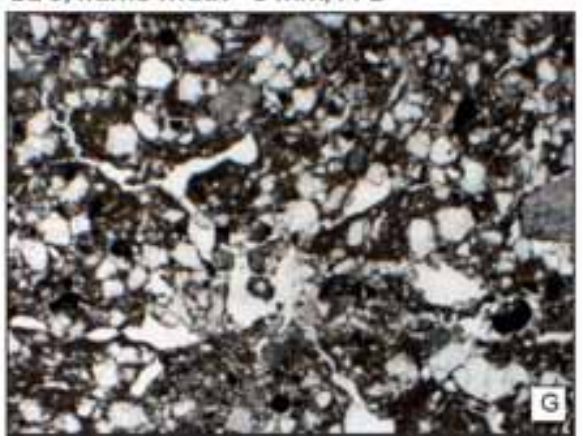

Same as $\mathrm{A}$ but XPL

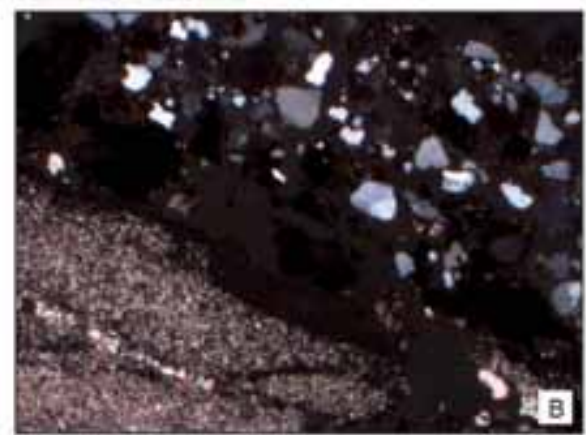

Same as C but XPL

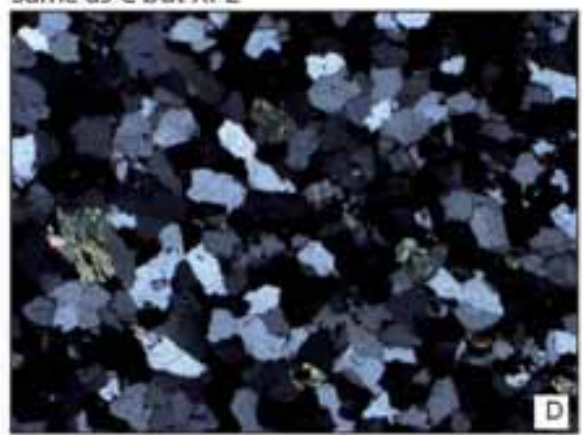

LG 4; frame width $\sim 2.5 \mathrm{~mm}$; XPL.

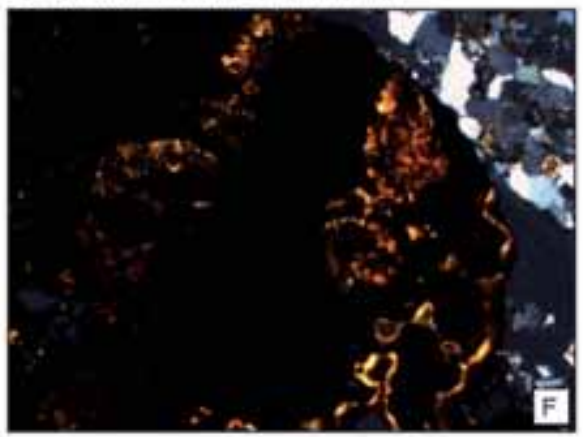

Same as $\mathrm{G}$ but partially crossed polarizers

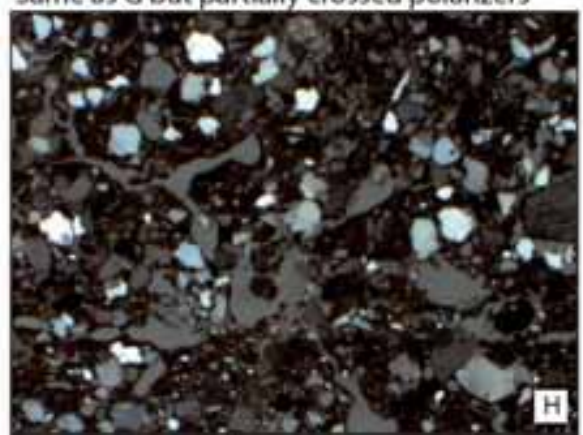

Figure 8. Micrographs showing selected sediment features of the sequence at La Güelga. A, B: Limestone fragment with phosphatic rim on top (PPL, XPL); C, D: Piece of quartzite that shows interlocking of quartz crystals and few green polycrystalline mineral grains (PPL, $\mathrm{XPL}$ ); E: Flint with dotted appearance, sharp boundaries and smooth surfaces (XPL); F: Opaque grain with pores and birefringent coatings $(\mathrm{XPL}) ; \mathrm{G}, \mathrm{H}$ : Well developed sub-angular blocky microstructure in Mousterian level $4 \mathrm{~b}$ of the exterior sequence. The sand grains are mainly composed of quartz.

Figura 8. Micrografías que muestran características especiales del sedimento en La Güelga. A, B: Fragmento de caliza con un borde fosfatado en la parte superior (PPL, XPL); $C$, D: Fragmento de cuarcita que muestra un entrelazamiento de cristales de cuarzo y unos pocos granos de mineral verde policristalino (PPL, XPL); E: Sílex con apariencia moteada, bordes afilados y superficie regular (XPL); G, H: Microestructuras de bloques subangulares bien desarrolladas en el nivel musteriense $4 b$ de la secuencia de la zona $D$ exterior. Los granos de arena son principalmente de cuarzo. 
Kehl, M., et al., 2018. Towards a revised stratigraphy for the Middle to Upper... Boletín Geológico y Minero, 129 (1/2): $183-206$

\begin{tabular}{|c|c|c|c|c|c|c|c|c|c|c|}
\hline Sample & Level & $\begin{array}{l}\text { Allochthon } \\
\text { ous quart- } \\
\text { zite }\end{array}$ & Flint & Charcoal & Bone & $\begin{array}{l}\text { Burnt } \\
\text { bone }\end{array}$ & $\begin{array}{l}\text { Phosphate } \\
\text { rims }\end{array}$ & Coprolites & $\begin{array}{l}\text { Secondary } \\
\text { carbonate }\end{array}$ & $\begin{array}{l}\text { Packing } \\
\text { density }\end{array}$ \\
\hline LG 1 & $1(\mathrm{CHA})$ & + & - & - & ++ & - & - & $(+)$ & + & Low \\
\hline LG 2 & 2 (CHA) & - & + & + & + & - & - & + & - & Low \\
\hline LG 4 & 4 (poor assemblage) & ++ & + & - & ++ & - & $(+)$ & + & - & Moderate \\
\hline LG 5 & 5 (AUR) & +++ & + & - & ++ & - & $(+)$ & + & - & $\begin{array}{l}\text { Moderate } \\
\text { to high }\end{array}$ \\
\hline LG 6 & 6 (AUR) & +++ & + & + & + & - & + & + & - & \begin{tabular}{|l} 
Moderate, \\
partially \\
low
\end{tabular} \\
\hline LG 8 & 8 (MOU) & ++ & ++ & + & ++ & + & - & $(+)$ & - & $\begin{array}{l}\text { Moderate } \\
\text { to high }\end{array}$ \\
\hline LG 9 & 9 (MOU) & +++ & + & ++ & +++ & ++ & + & $(+)$ & - & $\begin{array}{l}\text { Very low } \\
\text { to high }\end{array}$ \\
\hline LG P1 & Bioturbated zone & + & - & + & + & - & - & $(+)$ & - & Very low \\
\hline LG 3 & 3 (MOU) & - & + & - & + & - & - & - & ++ & $\begin{array}{l}\text { Low to } \\
\text { moderate }\end{array}$ \\
\hline LG 4b & $4 \mathrm{~b}$ (MOU) & + & ++ & ++ & +++ & + & - & $(+)$ & + & \begin{tabular}{|l|} 
Low to \\
moderate
\end{tabular} \\
\hline
\end{tabular}

Table 3. Summary of micromorphological features at La Güelga zone D.

Tabla 3. Resumen de las características micromorfológicas en la zona D de La Güelga.

ters ranging from less than $1 \mathrm{~mm}$ to $10 \mathrm{~mm}$ (Fig. 9C and D). The coprolites contain few mineral grains of silt to fine sand and have light grey colour and dotted limpidity. Occasionally, they contain vesicles with very thin clay coatings along the pore walls. Elongated pores with sharp edges, which may represent negatives of fur, are not present. There is also no clear evidence of plant remnants. In spite of their small size, an omnivore or carnivore origin of the coprolites is likely.

The thin sections do not show clear evidence for the presence of ash such as ash rhombs or clusters of fine calcite particles; however, ash and reddened sediments were encountered during field description of level 9 (Table 1) and related to combustion areas (Jordá Pardo et al., 2013). The lack of evidence for ash in thin section LG 9 may be caused by local dissolution of fine calcite particles in percolating water and carbonate leaching.

\section{Micromorphological features of the interior sequence}

The thin sections LG 1 and LG 2 contain comparatively few pieces of bone (LG 1) and flint (LG 2; Table 3, Fig. 7). Fragments of quartzite occur rarely (Table 3). There is very limited evidence for well-preserved charcoal with cell structures, but during field descrip- tion some pieces of charcoal have been found in level 1 (Table 1). Some small opaque particles, however, could represent charcoal or other organic burning residues, but more probably, most of the black particles consist of manganese oxides, which may have similar colour and luster under oblique incident light (cf.Table 3.2 of Stoops, 2003). Angular limestone fragments are common in LG 2. Few organic remnants of modern roots partly filled with excrements of mesofauna occur. The packing density is comparatively low. The large limestone fragment in the upper half of LG 1 shows a coating of secondary calcite along its lower left side. Coprolites are rarely detected in LG 1 but are more numerous in LG 2.

Levels 3 and 4 contain very few artefacts, which are of insecure cultural attribution. The stone rich level 3 (zone $D$ interior) probably represents a roof collapse (Jordá Pardo et al., 2013) and could not be sampled for micromorphology. The thin section LG 4 shows few small flint fragments, some quartzite fragments and bone. Coprolites are present in similar numbers as in LG 2. The upper third of the LG 4 includes a concentration of fine $(<10 \mathrm{~mm}$ in diameter $)$ limestone fragments, which probably delineates a sub-layer of level 4.

The thin sections LG 5 and LG 6 contain few flint particles, but the number of quartzite fragments is comparatively high. In LG 6, charcoal is more abun- 

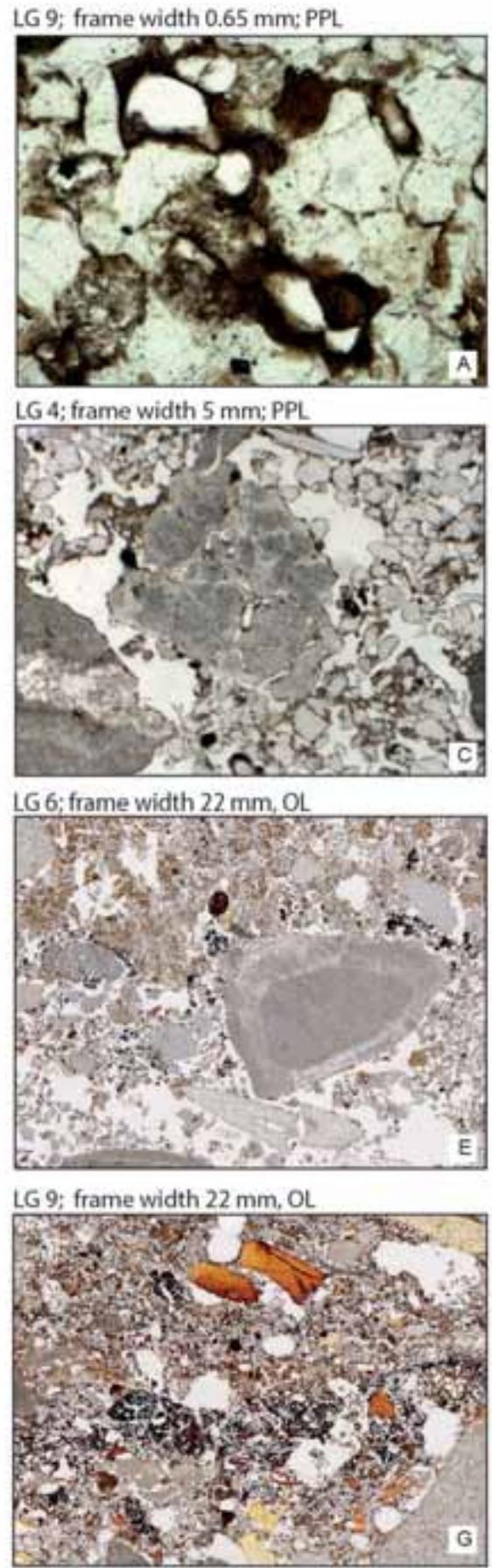

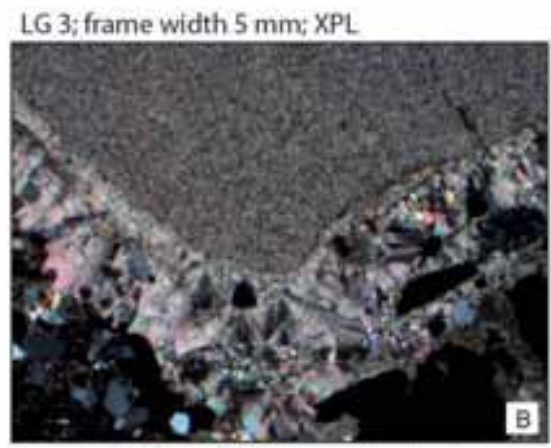

Same as C but partially crossed polarizers

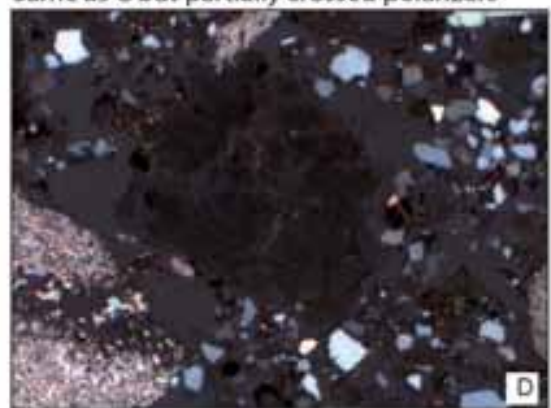

LG 9; frame width $\sim 5 \mathrm{~mm}$, PPL.

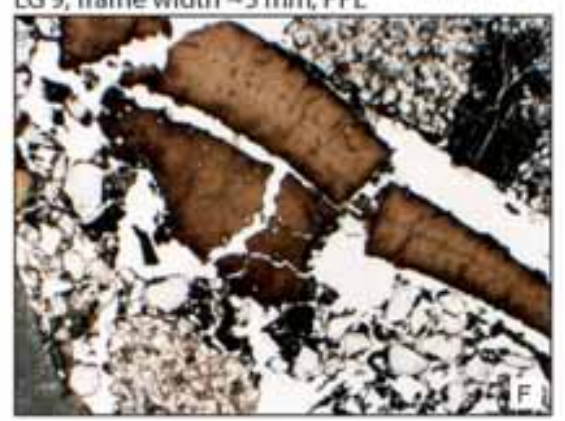

LG 6; frame width $22 \mathrm{~mm}, \mathrm{OL}$

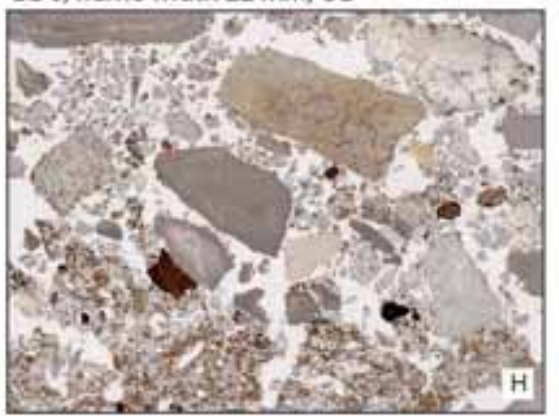

Figure 9. Micrographs and details of flatbed scans showing selected sediment features of the sequence at La Güelga. A: Fine dusty clay coatings in thin section LG 9; B: Calcite coatings below rock fragment; C, D: Light grey (PPL, XPL) coprolite with irregular pores; E: Broken bone and microstrata consisting of a loosely packed lower layer covered by more densely packed charcoal rich thin deposit and finally a light brown microlayer with larger amounts of fines at the top; F: Burned bone surrounded by groundmass enriched in charred organic material probably consisting of charcoal; G: Microlayers with different contents of charred materials; H: Microlayer with high content of rock fragments above microlayer with fines.

Figura 9. Micrografías y detalles de los escaneados de las láminas delgadas que muestran características seleccionadas del sedimento de la secuencia de La Güelga. A: Recubrimiento de arcillas finas pulverulentas en la lámina LG 9; B: Recubrimiento de calcita bajo un fragmento de roca; $C, D$ : Coprolito gris claro (PPL, XPL) con poros irregulares; E: hueso roto y microestrato consistente en una capa inferior de sedimento suelto cubierta por un depósito fino rico en carbones y una microcapa con grandes cantidades de finos en la parte superior; F: Hueso quemado rodeado por conjunto base enriquecido en materia orgánica carbonizada consistente probablemente en carbones; G: microcapas con diferente contenido en materiales carbonizados; H: Microcapa con alto contenido en fragmentos de roca sobre una microcapa con finos. 
Kehl, M., et al., 2018. Towards a revised stratigraphy for the Middle to Upper... Boletín Geológico y Minero, 129 (1/2): $183-206$

\begin{tabular}{|c|c|c|c|c|c|}
\hline Sample & Level & Compaction by trampling & Microstratification & \begin{tabular}{|l|} 
Preferred orientation \\
of elongated clasts
\end{tabular} & Lateral Reworking \\
\hline LG 1 & 1 (CHA) & Not indicated & None & Low & Likely \\
\hline LG 4 & 4 (poor assemblage) & Weak & Weak & Moderate & Possible \\
\hline LG 5 & 5 (AUR) & Moderate in the lower part & Weak & Moderate to clear & Unlikely \\
\hline LG 6 & 6 (AUR) & At internal boundary & Clear & Clear & Very unlikely \\
\hline LG 9 & 9 (MOU) & In microlayer, above char rich layer & Very clear & Clear & Very unlikely \\
\hline LG P1 & Bioturbated zone & Not indicated & None & None & Strong bioturbation \\
\hline LG 3 & 3 (MOU) & Not indicated & None & Moderate (1) & Likely (1) \\
\hline
\end{tabular}

Table 4. Micromorphological features at La Güelga zone D useful for distinguishing in-situ from reworked archaeological layers.

Tabla 4. Características micromorfológicas útiles para distinguir los niveles arqueológicos in situ de los niveles revueltos.

dant than in thin sections from overlying levels. The packing density is moderate to high. Thin section LG 6 shows clear microstratification indicated by differential degrees of compaction and presence of charcoal rich sub-layers (Fig. $8 \mathrm{~A}$ and $\mathrm{B}$ ). Also, elongated coarse components show a trend to parallel orientation of long axis with a slight dip towards the right hand side. In addition, a broken piece of bone is present, probably fractured during trampling, which compacted the overlying microlayer (Fig. $9 \mathrm{E}$ ). Coprolites are most frequent and attain the largest size in thin section LG 6 .

Level 7, intercalated between the Aurignacian and Mousterian levels 6 and 8, respectively, was not sampled. It is rich in stones and yielded very few archaeological finds. This layer represents a period of natural deposition related to roof collapse and probably non-occupation of the cave.

The thin sections LG 8 and LG 9 from the Mousterian levels are comparatively rich in flint, and charcoal fragments, respectively (Table 3, Fig. 7). In both thin sections, fragments of bone often show dark brown colour resulting from heat exposure during burning (Fig. 9 F). Particularly high contents of charcoal are present in a dark coloured layer within the upper third of thin section LG 9, where they occur in association with heated bone particles. Discontinuous interfaces between charcoal rich and charcoal poor microlayers are well expressed indicating microstratification (Fig. $9 \mathrm{G}$ ). Elongated fragments show some preferential orientation of their long axis. The degree of compaction varies strongly. Coprolites occur in small numbers.
Thin section LG P1 was extracted from an obviously bioturbated part of the sequence. It displays very loosely packed sediments. Rock fragments, sediment aggregates and other larger units do not show any accommodation. The pore space is characterized by complex packing voids between crumbs and granules, as well as by chambers, which are often produced by soil mesofauna (Kooistra and Pullemann, 2010). The contents of charcoal and bone is low, flint and burnt bone are not present. Few coprolites were detected. Features of in-situ archaeological deposits are lacking (Table 4). Occasional burrows and passage features reflecting a lower intensity of bioturbation occur in other thin sections as well. A burrow partly filled with mineral grains and soil granules is preserved in the centre of thin section LG 5 (Fig. 5).

\section{Micromorphological features of the exterior sequence}

The archaeological level $4 \mathrm{~b}$ of the exterior deposits probably correlates with level 9 of the interior sequence (Jordá Pardo et al., 2013). The thin section LG $4 \mathrm{~b}$ shows high amounts of bone and flint (Table 3 ). Charcoal fragments occur in very limited numbers, but field inspection during excavation yielded numerous charcoal fragments. A large angular fragment of quartzite is present. Thin section LG $4 b$ has a dark colour of the groundmass and mineral composition similar to the thin sections LG 8 and LG 9 from the interior Mousterian levels. In contrast, layering of charcoal rich material and burned bone fragments is not 
expressed in LG 4b. According to field evidence, level $4 \mathrm{~b}$ is very rich in rock fragments and the archaeological finds are densely packed in between them. On the one hand, it appears unlikely that microstratified archaeological deposits formed under these conditions. On the other hand, formation of secondary structure indicated by a well-developed subangular blocky microstructure and frequent chambers reflecting bioturbation may have contributed to the breakup of microlayers and mixing of fragments into the matrix.

The thin section LG3 shows a stone rich slope deposit with many calcite pedofeatures. These include coatings, more frequently found on the lower than upper side of limestone fragments, typical nodules, hypocoatings and some infillings of micrite and very rarely sparite. For illustration, the calcite coatings are mapped in Figure 7. The number of bone and flint fragments is low. Charcoal was not found. Clear indications for an in-situ archaeological layer are lacking. In the field, elongated clasts show imbricated fabric, related to soil creep along the slope. The intact coatings of secondary carbonate indicate that there was no reworking after their formation.

The sediments in the exterior sector (thin sections LG $4 \mathrm{~b}$ and LG 3) show more and clearer features of soil formation than thin sections from the cave sediments, which were protected from weathering and pedogenesis. The exterior sequence shows well developed stipple speckled, parallel striated and granostriated b-fabrics, frequent impure clay coatings, more strongly expressed subangular blocky microstructure and coatings and nodules of secondary carbonate.

\section{Distinction between undisturbed and reworked archaeological levels in the interior sequence}

The primary position of archaeological sediments is indicated by several micromorphological features. The first group relates to compaction by trampling. This process is indicated by the presence of crushed materials such as bone or shell (e.g., Goldberg et al., 2009; Miller et al., 2010; Linstädter and Kehl, 2012; Estévez et al., 2014). In addition, differential compaction of sediment or deformation of sediment components such as organic fibres (Goldberg et al., 2009) may be further indicators of trampling. Trampling is indicated in thin sections 5, 6, 8 and 9 from the interior sequence of La Güelga, where crushed bone is present or differentially compacted layers are evident (Fig. $9 \mathrm{E}$ and F).

The second characteristic is microstratification (e.g., Courty, 2001), i.e. the vertical alternation of dif- ferent materials in distinct and more or less continuous layers within the same level. Microstratification may involve intercalation of charcoal-rich microstrata (Figs. $8 \mathrm{~A}$ and $9 \mathrm{E}$ and $\mathrm{G}$ ) or layers of different median grain-size (Fig. $9 \mathrm{H}$ ). It can be expected that in-situ preserved archaeological layers show microstrata, because dwelling in a cave by humans involves dropping of different materials on the occupation surface. Depositional or structural crusts, which typically form at the land surface due to raindrop impact or sheet flow (Pagliai and Stoops, 2010) represent special forms of microstratification. Remnants of these socalled surface seals were detected in Mousterian layer 9 of the Sima de las Palomas de Teba and interpreted as evidence for a sequential accumulation of the sediment during human occupation (Kehl et al., 2013). Mixing by bioturbation, frost action or transport along a slope would destroy interfaces of internal layers and would finally lead to vertically unstratified levels.

Finally, if a living floor existed, it appears likely that the long axes of elongated fragments such as bone, lithic artefacts or limestone grit were deposited parallel to this surface resulting in planar orientation of elongated elements. If several elongated fragments are observed in thin section with parallel orientation of their long axes, it is likely that these particles occur in planar, linear or imbricated orientation. At La Güelga, preferential horizontal to subhorizontal orientation of elongated fragments is more strongly expressed in thin sections and impregnated blocks of LG 6, 8 and 9, while it is less in LG 1, 2, 4 and 5 (Table 4). However, the distinction is not very clear. Preferential orientation of elongated clasts may result from deposition by overland flow or lateral soil creep. In both cases, elongated grains often show an oblique orientation inclined towards the direction of flow (Betran and Texier, 1999; Mücher et al., 2010). This feature and other indicators of fluvial action such as graded bedding or erosional surfaces were not recorded during excavation and sampling of profiles of the interior sequence. It appears highly unlikely that high energy flow, which would be needed to transport and align large rock fragments or other elongated particles, affected the sequence. Soil creep may be responsible for imbrication of grains in the slope deposits of the exterior sequence, which is reflected in slight subhorizontal orientation of clasts in thin section LG 3 . Parallel inclination of clasts was not observed in the profile of the interior sequence in the field.

In the presumably Châtelperronian levels 1 and 2 most micromorphological characteristics indicating undisturbed archaeological levels are not evident. Overall, the micromorphological facies of layers 1 
and 2 share many features with poorly sorted, porphyric material encountered in slope deposits (Betran and Texier, 1999). Therefore, it is likely that the sediments of levels 1 and 2 were transported into the interior part of the cave. Since indicators of fluvial reworking such as laminations or graded bedding are not present, slow processes of reworking and transport during soil creep may have been responsible for transport of sediments and enclosed artefacts. The low accessibility of the shelter due to the limited height of the opening during accumulation of levels 3 to 1 would support this hypothesis. Furthermore, the cuniform geometry of the sediment layers 2 and upper in the interior sequence suggests that its upper part was deposited by slope processes rather than by human action.

Considering the micromorphological features and the number of artefacts retrieved during excavation it also appears likely that during accumulation of level 5 the cave was rarely occupied and that it was not used for the preparation of fire.

\section{Radiocarbon dating}

Two new radiocarbon dates were received for a bone fragment taken from level 2. The uncalibrated ages obtained on the same bone show a difference of almost 3,000 years (Table 5). However, due to the high standard deviation of the sample OxA-27958, the calibrated ages show overlap of their 95\%-probability intervals. The two dates cover the time between 41.46 and $45.91 \mathrm{ka}$ cal BP (Fig. 10). In contrast, the previous dating results for levels 1 and 2 (Beta-172343 and Beta-172344) yielded considerably younger 95\%probability age intervals (Table 5). The more rigorous pre-treatment methods applied before measuring of the new sample probably eliminated contamination with young ${ }^{14} \mathrm{C}$ more efficiently than the older protocols used by Beta Analytics. Furthermore, it is much likely that the ${ }^{14} \mathrm{C}$ ages of $29.55 \pm 0.31 \mathrm{ka}$ BP (Beta$172345)$ and $29.02 \pm 0.26$ ka BP (Beta-186766) for the exterior levels $4 a$ and $4 b$, respectively, considerably underestimate the time of Mousterian occupation and should be disregarded (Jordá Pardo et al., 2013).

It is not clear if these new ages date the Châtelperronian occupation, because the deposit itself may be reworked, as suggested by micromorphological evidence, and bone fragments older or younger than the occupation could be intermixed. If they do, the Châtelperronian occupation took place between accumulation of the Mousterian and Aurignacian levels (Fig. 10).

A series of six ${ }^{14} \mathrm{C}$ datings from the Oxford labora- tory (Table 5) using ultrafiltration fell towards the limit of the radiocarbon dating method and places the Mousterian levels 9 (interior sequence) and 4b (exterior sequence) to later than about 43 ka BP (Jordá Pardo et al., 2012; Higham et al., 2014). The new ages for level 2 are considerably younger than these six ages. The difference is quite clear although there is a slight overlap in the $95 \%$-probability intervals of samples OxA-27958 from level 2 and of all previous samples from levels 9 and $4 \mathrm{~b}$ provided by the Oxford laboratory. This is partly due to a comparatively large measuring error at Oxford resulting in standard deviations of 800 and more years.

The different bone samples were used for age determination in two different labs using conventional or ultrafiltration pre-treatment methods. Including the results for Beta-377233, the ${ }^{14} \mathrm{C}$ ages range from $33.61 \pm 0.22 \mathrm{ka} \mathrm{BP}$ to $34.75 \pm 0.6 \mathrm{ka} \mathrm{BP}$ which, after calibration, converts to a time window between $~ 35.6$ and $41.7 \mathrm{ka}$ cal BP. The new data for level 5 suggest that the Aurignacian occupation took place after the presumably Châtelperronian one. In addition, age inversion towards the top supports the notion that at least level 2 consists of reworked sediments. The measurements using pre-treatment with or without ultrafiltration at two different labs and the Beta Analytics date show excellent agreement and indicate that old bone sample can also be dated well without ultrafiltration if the collagen is relatively well preserved.

\section{Chrono-cultural ascription of the presumably Châtelperronian assemblage}

Apart from the taphonomic and chronometric data, some remarks have to be made regarding the chronocultural ascription of the lithic assemblages of layers 1 and 2. The postulated Châtelperronian evidence only rests on the occurrence of one Châtelperron point within level 1. Although this artefact falls within the variability of Châtelperron points, the attribution of small lithic assemblages to a specific technocomplex due to the presence of a so-called chronological significant artefact (fossiles directeurs) is seen to be problematic. Evidence for Châtelperronian occupations on the Iberian Peninsula is generally scarce and restricted to the northern part of Spain. Except for the rich lithic assemblage of the open air site of Aranbaltza (Rios-Garaizar et al., 2012) and site of Cueva Morín in Cantabria (González-Echegaray and Freeman, 1971 and 1973; Maíllo-Fernández, 2005), where the assemblage of the respective layer 10 contained more than 10,000 lithic artefacts, the other 


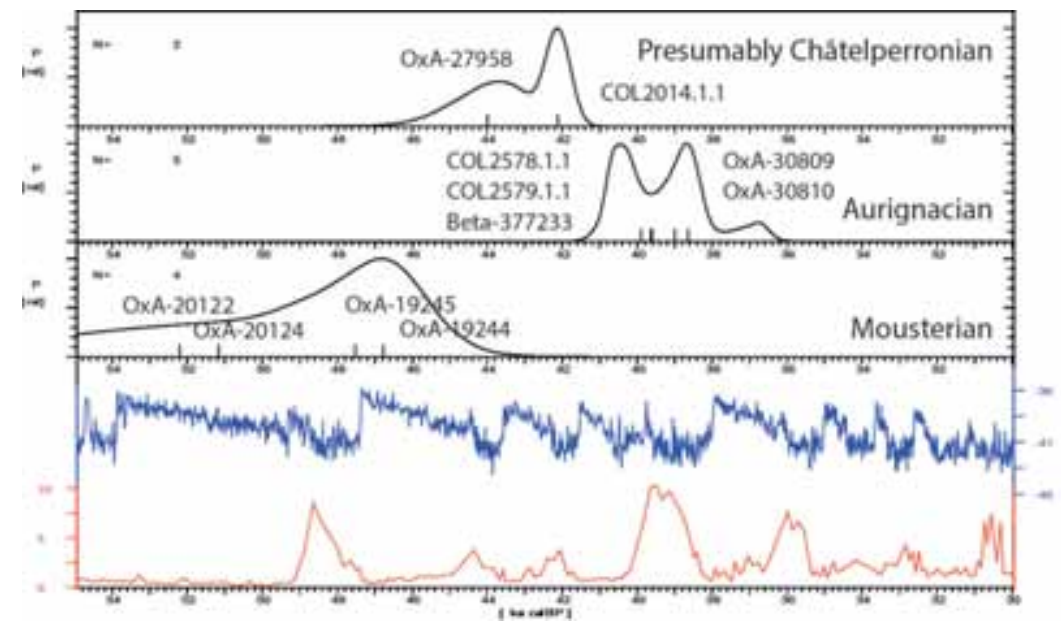

Figure 10. Results of radiocarbon datings on bone from Menéndez et al. (2014, Beta 377233), Quesada López and Menéndez Fernández (2009, OxA 19244, 19245 from level 9, 20122, 20124 from level 4b) and this study (all other dates). Note that the bone extracted from level 2 (presumably Châtelperronian) yielded two ages sandwiched by the dates for the Aurignacian and Mousterian levels. The blue line shows the GRIP delta ${ }^{18} \mathrm{O}$ values reflecting changes in temperature over Greenland (Johnsen et al., 2001). The red line is the C37:4 alkenone record (in \%) of marine core MD01-2444 retrieved from the lberian margin reflecting cold water searches towards the southwestern coasts of Iberia (Martrat et al., 2007).

Figura 10. Resultados de las dataciones de radiocarbon sobre hueso a partir de Menéndez et al. (2014, Beta 377233), Quesada López y Menéndez Fernández (2009, OxA 19244, 19245 del nivel 9; 20122, 20124 del nivel 4b) y este estudio (todas las demás fechas). Resaltar que el hueso extraído en el nivel 2 (presumiblemente chatelperroniense) aportó dos fechas enmarcadas entre las fechas de los niveles auriñacienses y musterienses. La línea azul muestra los valores del GRIP delta ${ }^{18} \mathrm{O}$ reflejando los cambios en la temperature sobre Greenland (Johnsen et al., 2001). La línea roja es el registro de alquenonas C37:4 (en \%) del sondeo marino MD01-2444 recuperado en el margen ibérico y que refleja búsquedas de agua fría hacia las costas del suroeste ibérico (Martrat et al., 2007).

assemblages, such as Labeko Koba or Ekain, are small and rather undiagnostic and mostly contain singular Châtelperron points. At Labeko Koba a prevalence of laminar blanks within the small assemblage has been perceived as further evidence to link it with classical French Châtelperronian sites (Arrizabalaga, 2000). For the Cantabrian Cordillera, MaílloFernández (2005 and 2007) only considered the sites of Labeko Koba in the Basque Country (Arrizabalaga, 2000) and Cueva Morín as Châtelperronian assemblages agreed with the French sites. To the contrary, Maroto et al. (2005) stressed the fact that the lithic assemblages, which contained Châtelperron points such as Arbreda or Ermitons, showed a clear Middle Palaeolithic affinity from both a technological as well as from a typological point of view. Correspondingly, these assemblages have been labelled "Mousterian with Châtelperron points", pinpointing towards the differences with the classical Châtelperronian sites of e.g. Arcy-sur-Cure or Quincay. The underlying assumption of this cautious interpretation is that the Châtelperronian technocomplex is characterized by more than the mere presence of the eponymous points (Vaquero, 2006: 112). Although MaílloFernández considered layer 10 of Cueva Morín a classical Châtelperronian site, it has to be mentioned that the discoid concept and the production of flakes also played a major role within the blank production system of the respective layer (Maílo-Fernández, 2007: 101). Even if the application of the discoid concept has been reported from classic French sites (Connet, 2002), the predominant orientation of the blank production system towards long elongated forms is though the general characteristic of classic Châtelperronian blank production (Pelegrin and Soressi, 2007). In that sense, the Spanish Châtelperronian sites, including Cueva Morín, diverge from the typical French sites and are best described by Maroto et al., s (2005) definition and the emphasis of the Middle Palaeolithic character. The site of La Güelga with its scarce lithic evidence, characterized by a strong Middle Palaeolithic component such as, for example, the Levallois flakes may at best be described as "Mousterian with Châtelperron points" according to Maroto et al. (2005). However, the most probably reworked and re-deposited nature of the layers hamper a secure chrono-cultural attribution and question the synchrony of the archaeological remains within these two analytical units.

\section{Conclusions}

Thin sections from sediments of the Mousterian lev- 
Kehl, M., et al., 2018. Towards a revised stratigraphy for the Middle to Upper... Boletín Geológico y Minero, 129 (1/2): $183-206$

\begin{tabular}{|c|c|c|c|c|c|c|c|}
\hline Level & Sample & Lab-number & Material & Method & $14 C$ age in B.P. & Reference & $\begin{array}{l}\text { calibrated 14C } \\
\text { age in cal B.P. } \\
\text { (95\% interval) }\end{array}$ \\
\hline \multicolumn{8}{|l|}{ Interior } \\
\hline 1 (CHA) & & Beta-172343 & bone & Collagen & $32460 \pm 440$ & Menéndez et al. (2005) & $38680-35080$ \\
\hline 2 (CHA) & & Beta-172344 & bone & Collagen & $30210 \pm 340$ & Menéndez et al. (2005) & $34950-33910$ \\
\hline $2(\mathrm{CHA})$ & Bone 1 & OxA-27958 & bone & Collagen and UF & $40300 \pm 1200$ & $\begin{array}{l}\text { This study (see also } \\
\text { Higham et al., 2014) }\end{array}$ & $45910-42070$ \\
\hline 5 (AUR) & & Beta-377233 & bone & Collagen and UF & $33610 \pm 220$ & Menéndez et al. (2014) & \\
\hline 5 (AUR) & LG 1060 B2 & COL2578.1.1 & bone & Collagen & $34164 \pm 273$ & This study & $41470-37790$ \\
\hline 5 (AUR) & LG 1060 B2 & COL2578.2.1 & bone & Collagen and UF & $34355 \pm 751$ & This study & $41800-37160$ \\
\hline 5 (AUR) & LG 1060 B2 & OxA-30810 & bone & Collagen and UF & $33900 \pm 550$ & This study & $41860-36140$ \\
\hline 9 (MOU) & & OxA-19244 & bone & Collagen and UF & $43700 \pm 800$ & $\begin{array}{l}\text { Quesada López and } \\
\text { Menéndez Fernández } \\
\text { (2009) }\end{array}$ & $49020-44540$ \\
\hline 9 (MOU) & & OxA-19245 & bone & Collagen and UF & $44300 \pm 1200$ & $\begin{array}{l}\text { Quesada López and } \\
\text { Menéndez Fernández } \\
\text { (2009) }\end{array}$ & $50660-44380$ \\
\hline 4b (MOU) & & OxA-20123 & bone & Collagen and UF & $>43200$ & $\begin{array}{l}\text { Quesada López and } \\
\text { Menéndez Fernández } \\
\text { (2009) }\end{array}$ & - \\
\hline 4b (MOU) & & OxA-20124 & bone & Collagen and UF & $48500 \pm 3500$ & $\begin{array}{l}\text { Quesada López and } \\
\text { Menéndez Fernández } \\
\text { (2009) }\end{array}$ & $60200-44200$ \\
\hline $4 \mathrm{~b}(\mathrm{MOU})$ & & OxA-20125 & bone & Collagen and UF & $>43600$ & $\begin{array}{l}\text { Quesada López and } \\
\text { Menéndez Fernández } \\
\text { (2009) }\end{array}$ & - \\
\hline 4a (MOU) & & Beta-172345 & bone & Collagen & $29550 \pm 310$ & Menéndez et al. (2005) & $34540-33220$ \\
\hline $4 \mathrm{~b}(\mathrm{MOU})$ & & Beta-186766 & bone & Collagen & $29020 \pm 260$ & Menéndez et al. (2005) & $34200-32800$ \\
\hline
\end{tabular}

Table 5. Results of radiocarbon dating for zone $D$ at La Güelga. Besides the new ages presented here, the radiocarbon dates cited by Jordá Pardo et al. (2013) Table 1, are listed. Calibration was carried out using the CalPal-2007 Hulu curve, June 2007 version (www.calpal.de; Weninger and Jöris, 2008).

Tabla 5. Resultados de las dataciones por radiocarbon para la zona D de La Güelga. Además de las nuevas dataciones presentadas aquí, aparecen en la lista las fechas de radiocarbono mencionadas por Jordá Pardo et al. (2013) en Tabla 1. La calibración fue realizada empleando la curva Cal-Pal-2007 Hulu, versión de junio de 2007 (www.calpal.de; Weninger and Jöris, 2008). 
els at La Güelga show many features of undisturbed archaeological deposits including a large number of artefacts, bone, burnt bone and charcoal fragments as well as indications of compaction by trampling, internal layering (in particular in LG 9) and horizontal orientation of elongated fragments. In comparison, sediments from the Aurignacian levels provide less evidence for preservation of undisturbed deposits. For the presumably Châtelperronian levels, the lack of micromorphological features indicative for undisturbed deposits suggests that after the partial roof fall documented in level 3 of the interior sequence, sediments and the few embedded artefacts in the shelter were transported inwards by soil creep. After re-deposition inside the shelter, compaction by trampling was insignificant. The low accessibility of the shelter due to the limited height of the opening during the accumulation of levels 3 to 1 would support this hypothesis. From the micromorphological perspective, it appears most likely that the interstratification of Aurignacian levels between Mousterian and Châtelperronian levels is caused by reworking of sediments of levels 1 and 2 from an external location and deposition within the interior of the cave.

The radiocarbon data indicate younger ages for the Aurignacian than for the Châtelperronian levels. This supports evidence against an interstratification of the Aurignacian and adds to the picture of deposition of reworked sediments on top of the Aurignacian occupation surfaces. The chronostratigraphical gap between the Mousterian and Aurignacian occupation documented in the interior sequence covers a period of at least 2.5 ka between ca. 44.5 and $42 \mathrm{ka}$ cal BP. Considering the weak stratigraphical and archaeological evidence for Châtelperronian occupation, it appears unlikely that this period of abandonment was interrupted by more than occasional human visits to La Güelga. Most probably, the site does not indicate a continuous occupation during the Middle to Upper Palaeolithic transitional phase.

\section{Acknowledgements}

Financial support of project C1 of the Collaborative Research Centre 806 "Our Way to Europe" funded by the German Research Foundation (DFG) is gratefully acknowledged.

\section{References}

Angelucci, D. 2010. The recognition and description of knapped lithic artifacts in thin section. Geoarchaeology, $25,220-232$.
Arrizabalaga, A. 2000. Los tecnocomplejos líticos del yacimiento arqueológico de Labeko Koba (Arrasate, País Vasco). In: Arrizabalaga, A. and Altuna, J. (eds.), Hienas y Humanos en los albores del Paleolítico superior. Munibe (Antropologia - Arkeologia), 52, 193-343.

Bar-Yosef, O. and Bordes, J.-G. 2010. Who were the makers of the Châtelperronian culture? Journal of Human Evolution, 59, 586-593.

Beckmann, T. 1997. Präparation bodenkundlicher Dünnschliffe für mikromorphologische Untersuchungen. Hohenheimer Bodenkundliche Hefte, 40, 89-103.

Bertran, P. and Texier, J.P. 1999. Facies and microfacies of slope deposits. Catena, 35, 99-121.

Bertran, P., Lenoble, A., Todisco, D., Desrosiers, P.M. and Sørensen, M. 2012. Particle size distribution of lithic assemblages and taphonomy of Palaeolithic sites. Journal of Archaeological Science, 39, 3148-3166.

Bordes, J.-G. 2003. Lithic taphonomy of the Chatelperronian/Aurignacian interstratifications in Roc de Combe and Le Piage (Lot, France). In: D'Errico, F. and J. Zilhão (eds.), The Chronology of the Aurignacian and of the Transitional Technocomplexes: Dating, Stratigraphies, Cultural Implications. Trabalhos de Arquelogia, 33, 223-244.

Brock, F., Bronk Ramsey, C. and Higham, T. 2007. Quality Assurance of Ultrafiltered Bone Dating. Radiocarbon, 49, 187-192.

Brock, F., Geoghegan, V., Thomas, B., Jurkschat, K. and Higham, T.F.G. 2013. Analysis of Bone "Collagen" Extraction Products for Radiocarbon Dating. Radiocarbon, 55, 445-463.

Connet, N. 2002. Le Châtelperronien: Réflexions sur I'unité et l'identité techno-économique de l'industrie lithique. L'apport de l'analyse diachronique des industries lithiques des couches Châtelperroniennes de la grotte du Renne à Arcy-sur-Cure (Yonne). PhD dissertation, University of Lille I, $685 \mathrm{pp}$.

Courty, M.-A. 2001. Microfacies analysis assisting archaeological stratigraphy. In: Goldberg, P., Holliday, V.T., Ferring, C.R. (eds.), Earth Sciences and Archaeology, Kluwer Academic, New York, 205-239.

Courty, M.A., Goldberg, P. and Macphail, R.I. 1989. Soils and Micromorphology in Archaeology. Cambridge University Press, Cambridge, UK.

d'Errico, F., Zilhão, J., Julien, M., Baffier, D. and Pelegrin, J. 1998. Neanderthal acculturation in western Europe? A critical review of the evidence and its interpretation. Current Anthropology, 39, S1-S44.

Estévez, J., Villagran, X.S., Balbo, A.L. and Hardy, K. 2014. Microtaphonomy in archaeological sites: The use of soil micromorphology to better understand bone taphonomy in archaeological contexts. Quaternary International, 330, 3-9.

Fülöp, R.-H., Heinze, S., John, S. and Rethemeyer, J. 2013. Ultrafiltration of Bone Samples is Neither the Problem nor the Solution. Radiocarbon, 55, 491-500.

Goldberg, P. and Berna, F. 2010. Micromorphology and context: Geoarchaeology and Taphonomy. Quaternary International, 214: 56-62.

Goldberg, P. and Macphail, R.I. 2006. Practical and theoretical geoarchaeology. Blackwell, 454 pp. 
Goldberg, P., Miller, C.E., Schiegl, S., Ligouis, B., Berna, F., Conard, N.J. and Wadley, L. 2009. Bedding, hearths, and site maintenance in the Middle Stone Age of Sibudu Cave, KwaZulu-Natal, South Africa. Archaeological and Anthropological Sciences, 1, 95-122.

González-Echegaray, J. and Freeman, L.G. 1971. Cueva Morin. Publicaciones del Patronato de las cuevas prehistóricas de la provincia de Santander VI, 452 p.

González-Echegaray, J. and Freeman, L.G. 1973. Cueva Morin. Publicaciones del Patronato de las cuevas prehistóricas de la provincia de Santander X, 304 p.

Gravina, B., Mellars, P. and Bronk Ramsey, C. 2005. Radiocarbon dating of interstratified Neanderthal and early modern human occupations at the Châtelperronian type-site. Nature, 438, 51-56.

Higham, T., Douka, K., Wood, R., Ramsey, C.B., Brock, F., Basell, L., Camps, M., Arrizabalaga, A., Baena, J., Barroso-Ruiz, C., Bergman, C., Boitard, C., Boscato, P., Caparrós, M., Conard, N.J., Draily, C., Froment, A., Galvan, B., Gambassini, P., García-Moreno, A., Grimaldi, S., Haesaerts, P., Holt, B., Iriarte-Chiapusso, M.-J., Jelinek, A., Jordá Pardo, J.F., Maíllo-Fernández, J.-M., Marom, A., Maroto, J., Menéndez, M., Metz, L., Morin, E., Moroni, A., Negrino, F., Panagopoulou, E., Peresani, M., Pirson, S., de la Rasilla, Marco, Riel-Salvatore, J., Ronchitelli, A., Santamaria, D., Semal, P., Slimak, L., Soler, J., Soler, N., Villaluenga, A., Pinhasi, R. and Jacobi, R. 2014. The timing and spatiotemporal patterning of Neanderthal disappearance. Nature, 512, 306-309.

Hoyos, M. and Laville, H. 1982. Nuevas aportaciones sobre la estratigrafía y sedimentología de los depósitos del Paleolítico Superior de la Cueva de EI Pendo (Santander): sus implicaciones, Zephyrus, 34-35, 285-293.

Hublin, J.-J. 2015. The modern human colonization of western Eurasia: when and where? Quaternary Science Reviews, 118, 194-210.

Hublin, J.J., Talamo, S., Julien, M., David, F., Connet, N., Bodu, P. , Vandermeersch, B. and Richards, M.P. 2012. Radiocarbon dates from the Grotte du Renne and SaintCésaire support a Neandertal origin for the Châtelperronian. Proceedings of the National Academy of Sciences, 109, 18743-18748.

I.G.M.E. 1986. Mapa Geológico de España, E. 1:50.000. 31 (15-4) Ribadesella. Segunda serie, Primera edición. Instituto Geológico y Minero de España, Madrid.

Johnsen, S. J., Dahl-Jensen, D., Gundestrup, N., Steffensen, J. P., Clausen, H. B., Miller, H., Masson-Delmotte, V., Sveinbjrnsdottir, A. E. and White, J. 2001. Oxygen isotope and palaeotemperature records from six Greenland ice-core stations: Camp Century, Dye-3, GRIP, GISP2, Renland and NorthGRIP. Journal of Quaternary Science, 16, 299-307, 2001.

Jordá Pardo, J.F., Menéndez Fernández, M., Carral González, P., Quesada López, J.M. and Wood, R. 2013. Geoarchaeology and chronostratigraphy of the MiddleUpper Palaeolithic transition at the cave of La Güelga (Cangas de Onís, Asturias, Spain). In: Pastoors, A. and Auffermann, B., eds: Pleistocene Foragers on the Iberian Peninsula: Their Culture and Environment. Wissenschaftliche Schriften des Neanderthal Museums 7, 85-106.
Jordá Pardo, J.F., Menéndez, M., Carral, P., Quesada, J.M. and Wood, R. 2012. Radiocarbono y Cronoestratigrafía del registro pleistoceno de la zona $D$ de la cueva de La Güelga (Picos de Europa, Norte de España). Nuevas fechas ${ }^{14} \mathrm{C}$. In: Fernández González, L.P., Fernández González, A., Cuesta Fernández, A. and Bahamonde Rionda, J.R. (eds.), Geo-Temas, 13, 76 and Geo-Temas, 13 CD 3 pp..

Kehl, M., Burow, C., Cantalejo, P., Durán, J.J., Henselowsky, F., Klasen, N., Medianero, F.J., Ramos, J., Reicherter, K., Schmidt, C. and Weniger, C.-C. 2013. The Palaeolithic site Sima de Las Palomas de Teba, Southerrn Spain - Site formation processes and chronostratigraphy. Proc. of the VIII Reunión de Cuaternario Ibérico. La Rinconada, Sevilla, pp. 285-289.

Kooistra, M.J. and Pulleman, M.M. 2010. Features Related to Faunal Activity. In: Stoops, G., Marcelino, V., Mees, F. (eds.), Interpretation of Micromorphological Features of Soils and Regoliths. Elsevier, Amsterdam, pp. 397-418.

Lenoble, A. and Bertran, P. 2004. Fabric of Palaeolithic levels: methods and implications for site formation processes. Journal of Archaeological Science, 31, 457469.

Leroi-Gourhan, A. 1961. Les fouilles d'Arcy-sur-Cure (Yonne). Gallia Préhistoire, 4, 3-16.

Lévêque, F. and Vandermeersch, B.M. 1980. Découvertes de restes humains dans un niveau Castelperronien à SaintCésaire (Charente-Maritime). Compte rendues de I'Academie de Sciences Serie D, 29, 187-189.

Linstädter, J. and Kehl, M. 2012. The Holocene archaeological sequence and site formation processes at Ifri Oudadane, NE Morocco. Journal of Archaeological Science, 39, 3306-3323.

Maíllo-Fernández, J. M. 2005. La produccíon laminar en el Chatelperroniense de Cueva Morín: modalidades, intenciones y objetivos. Trabajos de Prehistoria, 62, 47-64.

Maíllo-Fernández, J. M. 2007. Le Châtelperronien en Espagne: mythes et réalités. Une approche technologique. In: Èvin, J. (ed.), "Aux conceptions d'aujourd'hui". Actes du Congrès du Centenaire de la Société Préhistorique Française: un siècle de construction du discours scientifique en Préhistoire, vol. 3. Avignon, 2125 septembre 2004. Société préhistorique française, Paris, 95-103.

Maroto, J., Vaquero, M., Arrizabalaga, Á., Baena Preysler, J., Baquedano, E., Jordá, J.F., Julià, R., Montes, R., Van Der Plicht, J., Rasines, P. and Wood, R. 2012. Current issues in late Middle Palaeolithic chronology: New assessments from Northern Iberia. Quaternary International, 247, 15-25.

Maroto, J., Vaquero, M., Arrizabalaga, Á., Baena Preysler, J., Carrión, E., Jordá Pardo, J., Artinón, M., Menéndez, M., Montes, R. and Rosell, J. 2005. Problemática cronológica del final del Paleolítico Medio en el Norte Peninsular. In: Lasheras, J. A. and Montes, R. (eds.), Actas de la reunión científica: Neandertales cantábricos, estado de la cuestión. Celebrada en el Museo de Altamira los días 2022 de Octubre de 2004. Monografías del Museo Nacional y Centro de Investigación de Altamira, 20, Santander 101-114. 
Martrat, B., Grimalt, J.O., Shackleton, N.J., Abreu, L. de, Hutterli, M.A. and Stocker, T.F. 2007. Four Climate Cycles of Recurring Deep and Surface Water Destabilizations on the Iberian Margin. Science, 317, 502-507.

Mellars, P. 1996. The Neanderthal Legacy: An Archaeological Perspective from Western Europe. Princeton University Press, Princeton.

Mellars, P. 2005. The Impossible Coincidence. A SingleSpecies Model for the Origins of Modern Human Behavior in Europe. Evolutionary Anthropology, 14, 12-27.

Mellars, P., Gravina, B. and Bronk Ramsey, C. 2007. Confirmation of Neanderthal/modern human interstratification at the Chatelperronian type-site. Proceedings of the National Academy of Sciences, 104, 3657-3662.

Menéndez, M., García, E. and Quesada, J. M. 2005. La transición Paleolítico Medio- Paleolítico Superior en la Cueva de la Güelga (Cangas de Onís, Asturias). Un avance a su registro. In: Lasheras, J. A. and Montes, R. (eds.), Neandertales cantábricos, estado de la cuestión. Monografías del Museo Nacional y Centro de Investigación de Altamira, 20. Ministerio de Cultura, Santander, 589-617.

Menéndez, M., Weniger, G.-C., Álvarez-Alonso, D., de Andrés-Herrero, M., García, E., Jordá, Kehl, M., Rojo, J., Quesada, J.M. and Schmidt, I. 2014. La Cueva de la Güelga. Cangas de Onís. Asturias. In: Sala Ramos, R. (ed.), Pleistocene and Holocene Hunter-Gatherers in Iberia and the Gibraltar Strait: The Current Archaeological Record. Burgos, 60-63.

Miller, C. E., Conard, N. J., Goldberg, P. and Berna, F. 2010. Dumping, sweeping and trampling: experimental micromorphological analysis of anthropogenically modified combustion features. P@lethnologie, 2, 25-37.

Montes, R. and Sanguino, J. 2001. La Cueva del Pendo, actuaciones arqueológicas 1994-2000. Asamblea Regional de Cantabria, Santander.

Montes, R., Sanguino, J., Martín, P., Gómez, A.J. and Morcillo, C. 2005. La secuencia estratigráfica de la cueva de El Pendo (Escobedo de Camargo, Cantabria): problemas geoarqueológicos de un referente cronocultural. In: Santonja, M., Pérez-González, A. and Machado, M. (eds.), Geoarqueología y patrimonio en la Península Ibérica $y$ el entorno mediterráneo, ADEMA, Almazán (Soria), 127-138.

Mücher, H., van Steijn, H. and Kwaad, F. 2010. Colluvial and Mass Wasting Deposits. In: Stoops, G., Marcelino, V. and Mess, F. (eds.), Interpretation of Micromorphological Features of Soils and Regoliths, Elsevier, Amsterdam, 37-48.

Pagliai, M. and Stoops, G. 2010. Physical and Biological
Surface Crusts and Seals. In: Stoops, G., Marcelino, V. and Mess, F. (eds.), Interpretation of Micromorphological Features of Soils and Regoliths, Elsevier, Amsterdam, 419-440.

Pelegrin, J. and Soressi, M. 2007. Le Châtelperronien et ses rapports avec le Moustérien. In: Vandermeersch, B. and Maureille, B. (eds.), Les Néandertaliens. Biologie et culture. Paris, Éd. du CTHS (Documents préhistoriques), 23, 283-296.

Quesada López, J.M. and Menéndez Fernández, M. 2009. Revisión cronoestratigráfica de la Cueva de La Güelga (Narciandi, Asturias). Del Musteriense al Paleolítico Superior Inicial. Espacio, Tiempo y Forma, Serie I Prehistoria y Arqueología, Nueva época, 2, 39-74.

Ramsey, C.B. 2004. Improvements to the pretreatment of bone at Oxford. Radiocarbon, 46, 155-163.

Ramsey, C.B., Higham, T.F.G. and Leach, P. 2004. Towards High-Precision AMS: Progress and Limitations. Radiocarbon, 46, 17-24.

Ramsey, C.B., Higham, T.F.G., Owen, D.C., Pike, A.W.G. and Hedges, R.E.M. 2002. Radiocarbon Dates from the Oxford AMS System: Archaeometry Datelist 31. Archaeometry, 44, 1-150.

Rethemeyer, J., Fülöp, R.H., Höfle, S., Wacker, L., Heinze, S., Hajdas, I., Patt, U., König, S., Stapper, B. and Dewald, A. 2013. Status report on sample preparation facilities for ${ }^{14} \mathrm{C}$ analysis at the new CologneAMS center. Nuclear Instruments and Methods in Physics Research B, 294, 168-172.

Rios-Garaizar, J., Libano Silvente, I. and Garate Maidagan, D. 2012. El yacimiento chatelperroniense al aire libre de Aranbaltza (Barrika, Euskadi). Munibe 63, 81-92.

Stoops, G. 2003. Guidelines for the analysis and description of soil and regolith thin sections. Soil Science Society of America, Madison, WI.

Vaquero, M. 2006. El tránsito Paleolítico Medio/Superior en la Península Ibérica y la Frontera del Ebro. Comentario a Zilhão (2006). Pyrenae, 37, 107-129.

Weninger, B. and Jöris, O. 2008. A 14C age calibration curve for the last $60 \mathrm{ka}$ : the Greenland-Hulu U/Th timescale and its impact on understanding the Middle to Upper Paleolithic transition inWestern Eurasia. Journal of Human Evolution, 55, 772-781.

Weninger, B., Jöris, O. and Danzeglocke, U. 2007. CalPal2007. Cologne Radiocarbon Calibration and Palaeoclimate Research Package, www.calpal.de.

Zilhão, J. and d'Errico, F. 1999. The chronology and taphonomy of the earliest Aurignacian and its implications for the understanding of Neanderthal extinction. Journal of World Prehistory, 33, 1-68.

Recibido: junio 2015

Revisado: diciembre 2015

Aceptado: enero 2016

Publicado: marzo 2018 